\title{
Transferability of Microsatellite Markers in the Betulaceae
}

\author{
Kahraman Gürcan ${ }^{1}$ and Shawn A. Mehlenbacher ${ }^{2}$ \\ Department of Horticulture, Oregon State University, 4017 ALS Building, Corvallis, OR 97331
}

\begin{abstract}
AdDitional Index words. Corylus avellana, hazelnut, filbert, Betula pendula, birch, simple sequence repeat
Abstract. Microsatellite-containing sequences for the Betulaceae (Betula, Corylus, and Alnus) were retrieved from GenBank and used to develop twelve new microsatellite marker primer pairs that amplified and were polymorphic in european hazelnut (Corylus avellana). The primer pairs were characterized using 50 european hazelnut accessions. Nine of these microsatellites that segregated in a mapping population were assigned to linkage groups. The 12 new primer pairs will be useful in genetic studies in Corylus and Betula. To investigate transferability of microsatellite primer pairs in the family Betulaceae, we assessed the ability of 129 simple sequence repeat (SSR) primer pairs (75 from Corylus, 52 from Betula, and two from Alnus) to amplify DNA of 69 accessions representing diverse taxa. Microsatellite primer pairs from Betula amplified $92 \%$ of Betula, $51 \%$ of Alnus, $41 \%$ of Corylus, $37 \%$ of Carpinus, 35\% of Ostryopsis, and 34\% of Ostrya accessions. In the 69 accessions, microsatellite primer pairs from Corylus amplified $81 \%$ of Corylus, $55 \%$ of Carpinus, $53 \%$ of Ostrya, $51 \%$ of Ostryopsis, $41 \%$ of Alnus, and $39 \%$ of Betula accessions. An additional 147 SSR primer pairs developed from Corylus, used to amplify a subset of 32 accessions, gave similar values: $92 \%$ in Corylus, $33 \%$ in Carpinus, 33\% in Ostrya, $44 \%$ in Ostryopsis, 35\% in Alnus, and 54\% in Betula. The high transferability $(>39 \%)$ of microsatellite primer pairs between Betula and Corylus will allow comparative studies of the two genera with the greatest economic importance.
\end{abstract}

European hazelnut belongs to the family Betulaceae, which is one of eight families of the Order Fagales. Betulaceae, which includes six genera and $\approx 140$ species, is subdivided into two clades, Betuloideae and Coryloideae. Betuloideae includes Alnus (35 species), and Betula (35-60 species), while Coryloideae includes Carpinus (35 species), Corylus (11-13 species), Ostrya (10 species), and Ostryopsis (two species) (Chen et al., 1999; Yoo and Wen, 2002). The basic chromosome number is 14 for Alnus and Betula, 11 for Corylus, and 8 for Carpinus, Ostrya, and Ostryopsis (Botta et al., 1986; Snow and Goldblatt, 1992). Betula species form a polyploid series, with chromosome numbers of 28, 56, 70, 84, and 112 (Järvinen et al., 2004), while Corylus species are diploid. Most species in the Betulaceae are wind-pollinated and monoecious. Most are distributed in temperate regions of the Northern Hemisphere, while Ostryopsis is endemic to eastern Asia. Despite the variation in chromosome number and genome size among species of the Betulaceae, some degree of microsatellite marker transferability is expected based on results in other plant families.

Microsatellites, also known as simple sequence repeats (SSR), are molecular markers that are highly polymorphic and abundant in plant genomes. Moreover, the transferability of SSR markers allows their use in related species for fingerprinting, mapping, and marker-assisted breeding. Examples include the high transferability of expressed sequence tag (EST)-SSRs from bread wheat (Triticum aestivum) to other cereals (Zhang et al., 2005), across the major pulses (Pandian et al., 2000), from apple (Malus $\times$ domestica) to european pear (Pyrus communis) (Pierantoni et al., 2004), from apricot (Prunus armeniaca) and grape (Vitis vinifera) to related taxa (Decroocq et al., 2003), from peach (Prunus persica) to related Prunus species (Cipriani et al., 1999), and from olive (Olea europaea) to other

Received for publication 3 Mar. 2010. Accepted for publication 1 Apr. 2010. ${ }^{1}$ Current address: Department of Horticulture and Landscape Architecture, PO Box 646414, Washington State University, Pullman WA 99164-6414.

${ }^{2}$ Corresponding author. E-mail: mehlenbs@hort.oregonstate.edu. species in the genus Olea (Rallo et al., 2003). Recent reviews of SSR transferability include Ellis and Burke (2007) and Barbara et al. (2007).

In this study, we developed new SSR markers based on DNA sequences of Alnus, Betula, and Corylus retrieved from a public database. We used these new SSR primer pairs, published polymorphic marker primer pairs for Betula, and markers developed in our laboratory for Corylus, to investigate their transferability in the family Betulaceae. Betula primer pairs that amplified in Corylus were characterized, and new primer pairs that segregated in our Corylus mapping population were assigned to linkage groups of the european hazelnut.

\section{Materials and Methods}

Plant material. A total of 50 hazelnut accessions, including the parents of our mapping population, were used to characterize the SSR primer pairs (Gürcan et al., 2010). Of these, 24 were used in the initial screening of markers. These 50 accessions were chosen as a diverse subset of the 198 unique accessions fingerprinted by Gökirmak et al. (2009). Trees of all hazelnut accessions were growing in the field at the U.S. Department of Agriculture-Agriculture Research ServiceNational Clonal Germplasm Repository (USDA-ARS-NCGR) and the Oregon State University Department of Horticulture's Smith Horticulture Research Farm in Corvallis. A mapping population of 144 seedlings (Mehlenbacher et al., 2006) was used for segregation analysis.

Sixty-nine genotypes representing six genera (Table 1), including 9 species of Alnus, 15 species of Betula, 4 species of Carpinus, 11 species of Corylus, 3 species of Ostrya, and 2 species of Ostryopsis, were used in the transferability study. Leaf material was obtained from several sources, including four in Corvallis, OR (USDA-ARS-NCGR, Smith Horticultural Research Farm, Oregon State University campus, and Peavy Arboretum), the Morris Arboretum of the University of Pennsylvania in Philadelphia, and the U.S. National Arboretum in Washington, DC. 
Table 1. Betulaceae species and accessions used to study transferability of microsatellite markers.

\begin{tabular}{|c|c|c|}
\hline Species & Cultivar or accession & Source $^{z}$ \\
\hline Alnus glutinosa & & OSU campus \\
\hline Alnus hirsuta & & U.S. National Arboretum \\
\hline Alnus incana & & OSU campus \\
\hline A. incana ${ }^{y}$ & & Peavy Arboretum \\
\hline Alnus japonica ${ }^{y}$ & & Peavy Arboretum \\
\hline Alnus rhombifolia ${ }^{y}$ & & Peavy Arboretum \\
\hline Alnus rubra & & OSU campus \\
\hline Alnus serrulata & & U.S. National Arboretum \\
\hline Alnus sinuta & & Peavy Arboretum \\
\hline Alnus tenuifolia & & Peavy Arboretum \\
\hline Betula albosinensis & & U.S. National Arboretum \\
\hline Betula alleghaniensis ${ }^{y}$ & & U.S. National Arboretum \\
\hline Betula chinensis & & U.S. National Arboretum \\
\hline Betula davurica & & U.S. National Arboretum \\
\hline Betula fruiticosa $a^{y}$ & & U.S. National Arboretum \\
\hline Betula grossa & & U.S. National Arboretum \\
\hline Betula jacquemontii & & OSU campus \\
\hline Betula lenta & & U.S. National Arboretum \\
\hline Betula maximowicziana ${ }^{y}$ & & U.S. National Arboretum \\
\hline Betula nigra & 'Heritage' & U.S. National Arboretum \\
\hline B. nigra & & OSU campus \\
\hline Betula ovalifolia & & U.S. National Arboretum \\
\hline Betula papyrifera & & U.S. National Arboretum \\
\hline B. papyrifera & & OSU campus \\
\hline Betula pendula & youngii & OSU campus \\
\hline B. pendula & & OSU campus \\
\hline B. pendula & laciniata & OSU campus \\
\hline B. pendula & purpurea & OSU campus \\
\hline Betula populifolia & & OSU campus \\
\hline Betula uber & & U.S. National Arboretum \\
\hline Carpinus betulus & fastigiata & OSU campus \\
\hline C. betulus & pendula & U.S. National Arboretum \\
\hline C. betulus ${ }^{y}$ & & U.S. National Arboretum \\
\hline C. betulus & & OSU campus \\
\hline Carpinus caroliniana $^{y}$ & & OSU campus \\
\hline C. caroliniana & & U.S. National Arboretum \\
\hline Carpinus cordata & & U.S. National Arboretum \\
\hline Carpinus turczaninovii ${ }^{y}$ & & U.S. National Arboretum \\
\hline Corylus americana & CCOR 193 & USDA-NCGR \\
\hline C. americana ${ }^{y}$ & CCOR $686(\mathrm{~N} 02.68)$ & USDA-NCGR \\
\hline Corylus avellana & 'Imperiale de Trebizonde' & USDA-NCGR \\
\hline C. avellana & 'Tombul' (V26a) & USDA-NCGR \\
\hline Corylus californica ${ }^{y}$ & $\# 2(\mathrm{~N} 2.66)$ & USDA-NCGR \\
\hline C. californica & CCOR239, SCS 59-1 (N05.57) & USDA-NCGR \\
\hline Corylus chinensis & OSU 529.001 & USDA-NCGR \\
\hline C. chinensis & OSU 567.005 & USDA-NCGR \\
\hline C. chinensis ${ }^{y}$ & W05 & USDA-NCGR \\
\hline Corylus colurna & CCOR453, N550 (N04.08) & USDA-NCGR \\
\hline C. colurna & $\mathrm{X}-11$ & USDA-NCGR \\
\hline Corylus cornuta ${ }^{y}$ & CC3.01 (N02.59) & USDA-NCGR \\
\hline C. cornuta & $\mathrm{CC} 3.113(\mathrm{~N} 07.04)$ & USDA-NCGR \\
\hline Corylus fargesii & $\# 83$ & USDA-NCGR \\
\hline C. fargesii & $96-574 J$ & USDA-NCGR \\
\hline C. fargesii $i^{y}$ & Gas Pump & USDA-NCGR \\
\hline Corylus ferox & OSU weather station & USDA-NCGR \\
\hline Corylus heterophylla ${ }^{y}$ & sutchuensis (N05.22) & USDA-NCGR \\
\hline C. heterophylla & CCOR 691 (N07.22) & USDA-NCGR \\
\hline C. heterophylla & D80-190 (V15) & USDA-NCGR \\
\hline
\end{tabular}

continued next page
DNA extraction. DNA from Corylus accessions and the mapping population was extracted from young leaves of field-planted trees, as described by Davis et al. (1998) and modified by Lunde et al. (2000). DNA was extracted from other genera using a modified Puregene extraction protocol (Gentra Systems, Minneapolis). Proteinase $\mathrm{K}$ and RNase $\mathrm{A}$ digestion steps were included in the extraction, and protein precipitation was repeated twice. All template DNA was diluted in TE buffer to $3.5 \mathrm{ng} \cdot \mu \mathrm{L}^{-1}$ before amplification.

MARKer Sources. Twenty new SSR markers were developed from sequences retrieved from GenBank (National Center for Biotechnology Information, 2010): 16 for Betula, 2 for Alnus, and 2 for Corylus. Thirtysix SSR primer pairs developed from genomic libraries in Betula (Kulju et al., 2004; Oygu et al., 2003; Truong et al., 2005; Wu et al., 2002) for which published observed heterozygosity was high $\left(\mathrm{H}_{\mathrm{o}} \geq 0.5\right)$ were also used. Ten Betula platyphylla primer pairs were from Wu et al. (2002) (Bp01, Bp04, Bp07, BpTA, Bp10, Bp11, Bp13, Bp15, Bp16, and BpA), 5 Betula maximowicziana primer pairs were from Oygu et al. (2003) (Bmax097, Bmax544, Bmax624, Bmax630, and Bmax 671), 15 Betula pendula primer pairs were from Kulju et al. (2004) (L2.2, L2.7, L3.1, L3.4, L37.1, L7.4, L4.4, L5.1, L5.4, L5.5, L7.3, L7.8, L13.1, L63, and L022), and $6 \mathrm{~B}$. pendula primer pairs were from Truong et al. (2005) (L1.10, L2.5, L021, Bo.F394, Bo.F330, and Bo.G182). Primer pairs developed from enriched libraries of Corylus avellana (Bassil et al., 2005a, 2005b; Boccacci et al., 2005; Gürcan et al., 2010), primer pairs developed from ISSR fragments (Gürcan, 2009), and new Corylus primer pairs from various sources (Table 2) were used in this study.

In 2006, all Betulaceae sequences were retrieved from the GenBank database: 3300 for Betula, 23 for Alnus, and 45 for Corylus. Unique sequences were identified using the sequence assembly program CAP3 (Huang and Madan, 1999) at the Oregon State University (OSU) Center for Genome Research and Biocomputing, and then 
Table 1. Continued.

\begin{tabular}{lll}
\hline Species & \multicolumn{1}{c}{ Cultivar or accession } & \multicolumn{1}{c}{ Source $^{z}$} \\
\hline C. heterophylla & yunnanensis 286 (N06.21) & USDA-NCGR \\
C. heterophylla & 'Ogyoo' (T26) & USDA-NCGR \\
Corylus jacquemontii & $\# 1(\mathrm{~N} 01.64)$ & USDA-NCGR \\
C. jacquemontii & $\# 2(\mathrm{~N} 07.65)$ & USDA-NCGR \\
Corylus sieboldiana & U2 (N05.55) & USDA-NCGR \\
C. sieboldiana & CCOR 350 (N02.61) & USDA-NCGR \\
Ostrya carpinifolia & & Morris Arboretum \\
Ostrya japonica & & Morris Arboretum \\
Ostrya virginiana & & OSU campus \\
Ostryopsis davidiana & & UC Botanical Garden \\
Ostrya nobilis & & UC Botanical Garden \\
\hline
\end{tabular}

${ }^{\mathrm{z} O r e g o n ~ S t a t e}$ University (OSU), Corvallis; Peavy Arboretum, OSU, Corvallis; U.S. National Arboretum, Washington, DC; U.S. Department of Agriculture-Agricultural Research ServiceNational Clonal Germplasm Repository (USDA-NCGR), Corvallis, OR; Morris Arboretum, University of Pennsylvania, Philadelphia; University of California (UC) Botanical Garden, Berkeley. ${ }^{y}$ Used to amplify 157 additional SSR loci from Corylus.

sequences were screened for the presence of SSRs with the program SSRIT (Temnykh et al., 2001). Primers that flanked the microsatellites were designed using the Primer3 program (Rozen and Skaletsky, 2000) with the following criteria: 22 to $24 \mathrm{bp}$ in length, $30 \%$ to $55 \%$ guanine-cytosine (GC) content, and $60{ }^{\circ} \mathrm{C}$ annealing temperature. From these database sequences, we developed 20 new SSR markers: 16 from Betula sequences, 2 from Alnus, and 2 from Corylus (Table 2).

Marker transferability. Polymerase chain reactions (PCRs) were conducted in a $15-\mu \mathrm{L}$ PCR mixture containing $0.3 \mu \mathrm{M}$ each of forward and reverse primers, $1 \times$ Biolase $\mathrm{NH}_{4}$ reaction buffer, $3 \mathrm{~mm} \mathrm{MgCl} 2,200 \mu \mathrm{M}$ of each dNTP, 3 to $5 \mathrm{ng}$ of template DNA, and 0.25 units of Biolase DNA polymerase (Bioline, Randolph, MA). The thermocycler was programmed to denature DNA at $94{ }^{\circ} \mathrm{C}$ for $3 \mathrm{~min}$, followed by 40 cycles of $94{ }^{\circ} \mathrm{C}$ for $40 \mathrm{~s}$, annealing temperature for $60 \mathrm{~s}, 72{ }^{\circ} \mathrm{C}$ for $60 \mathrm{~s}$, and a final 7 -min extension step at $72{ }^{\circ} \mathrm{C}$. PCR products were separated by electrophoresis through $3 \%$ agarose. The gels were stained with ethidium bromide, placed under ultraviolet light, and photographed using an imaging system (UVP, Upland, CA). Amplification was indicated by visible bands of the expected size (intense or faint) on the agarose gels. Amplifications that gave multiple bands with a large size range were scored as zero and were not considered transferable.

Characterization of polymorphic markers. The initial screening of the new markers in C. avellana used 24 accessions (Gürcan et al., 2010) and the PCR mixture and thermocycler program described above. PCR products were separated on 3\% agarose gels, and polymorphic primer pairs were identified visually. For polymorphic primer pairs, forward primers were labeled fluorescently with 6-FAM, HEX, or NED and were used to amplify 48 accessions plus the parents of our mapping population (OSU 252.146 $\times$ OSU 414.062) (Mehlenbacher et al., 2006) using the same PCR cocktail and thermocycler program described above. PCR products, $1 \mu \mathrm{L}$ from each of four primer pairs, were multiplexed by diluting in $80 \mu \mathrm{L}$ of distilled water. A $1-\mu \mathrm{L}$ aliquot of the mixture was sent to the Core Laboratories of the OSU Center for Genome Research and Biocomputing where fragment sizes were determined using a capillary electrophoresis instrument (ABI 3100; Applied Biosystems, Foster City, CA).
Expected heterozygosity $\left(\mathrm{H}_{\mathrm{e}}\right)$, observed heterozygosity $\left(\mathrm{H}_{\mathrm{o}}\right)$, and polymorphic information content (PIC) were calculated for the polymorphic primer pairs using PowerMarker (Liu and Muse, 2005). $\mathrm{H}_{\mathrm{e}}$ was calculated according to the formula $\mathrm{H}_{\mathrm{e}}=1-\sum p_{\mathrm{i}}{ }^{2}$, where $p_{i}$ is the frequency of the $i^{\text {th }}$ allele (Nei, 1973). $H_{o}$ was from direct counts, and the PIC value for each locus was estimated using PowerMarker as $P I C=1-\sum_{i} p_{i}^{2}-\sum_{i=1} \sum_{j=i+1} 2 p_{i}^{2} p_{j}^{2}$ where $p_{i}$ and $p_{j}$ are the frequencies of the $i^{\text {th }}$ and $j^{\text {th }}$ alleles, respectively. The frequency of null alleles (r) was estimated as $\mathrm{r}=\left(\mathrm{H}_{\mathrm{e}}-\mathrm{H}_{\mathrm{o}}\right) /\left(1+\mathrm{H}_{\mathrm{e}}\right)$ (Botstein et al., 1980) in a spreadsheet (Table 3).

Segregation and mapping of POLYMORPHIC MARKERS. Observed segregation ratios in the mapping population were compared with expected Mendelian ratios using chi-square goodness-of-fit tests (Table 4). The new markers were placed on the hazelnut linkage map using JoinMap 3.0 (van Ooijen and Voorrips, 2001) as described by Mehlenbacher et al. (2006). The Kosambi mapping function was used for the calculation of map distances and a LOD score of 7.0 was used for the determination of linkage groups.

\section{Results and Discussion}

DEVELOPMENT OF NEW MARKERS FROM DATABASE SEQUENCES. We downloaded 3368 sequences from GenBank: 3300 for Betula, 23 for Alnus, and 45 for Corylus. Alignment of the Betula sequences resulted in 527 contigs and 605 singlet fragments. In these 1132 unique fragments, 254 fragments contained SSRs with repeats $\geq 10 \mathrm{bp}$, of which 35 contained repeats $\geq 20 \mathrm{bp}$. Comparison of these 35 with published SSR-containing sequences revealed that 19 had already been used for SSR marker development, while 16 had not yet been used. All 23 Alnus sequences were unique; four SSR-containing regions were $\geq 10$ $\mathrm{bp}$, of which two in a single sequence had SSRs $\geq 20 \mathrm{bp}$. All 45 Corylus sequences were unique; 10 regions in these sequences had SSRs $\geq 10 \mathrm{bp}$, of which three in a single sequence had repeats $\geq 20$ bp. Unique sequences with SSRs $\geq 20$ bp (16 from Betula, 2 from Alnus, and 3 from Corylus) were used to develop SSR markers. Of the 16 Betula primer pairs, 6 failed to amplify in Corylus, and only 4 of the 10 that amplified Corylus were polymorphic. Of the two Alnus primer pairs, one failed to amplify in Corylus, and the other generated monomorphic products. Three Corylus primer pairs were designed from a single sequence. Two (AJ417975b and AJ417975c) produced polymorphic bands, but amplification with the third primer pair (AJ417975a) was poor and the locus was not investigated further. Only AJ417975c segregated in the mapping population.

ChARACTERIZATION AND MAPPING OF POLYMORPHIC PRIMER PAIRS. Four articles describe the development of 52 markers for Betula (Kulju et al., 2004; Oygu et al., 2003; Truong et al., 2005; Wu et al., 2002). For 36 of these markers, observed heterozygosity was $\geq 0.5$. DNA from at least 18 of 24 Corylus accessions was amplified using the published primer sequences 


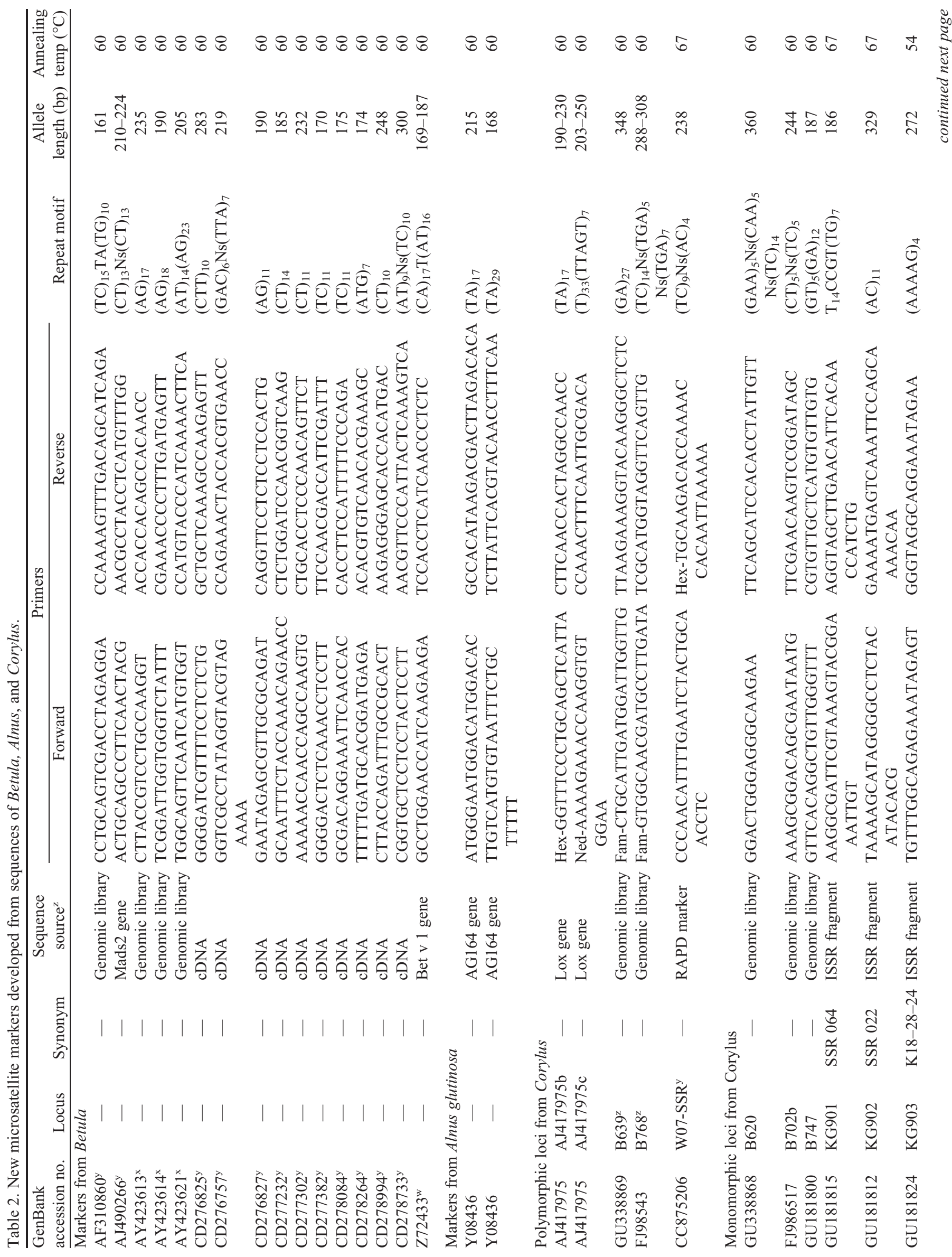




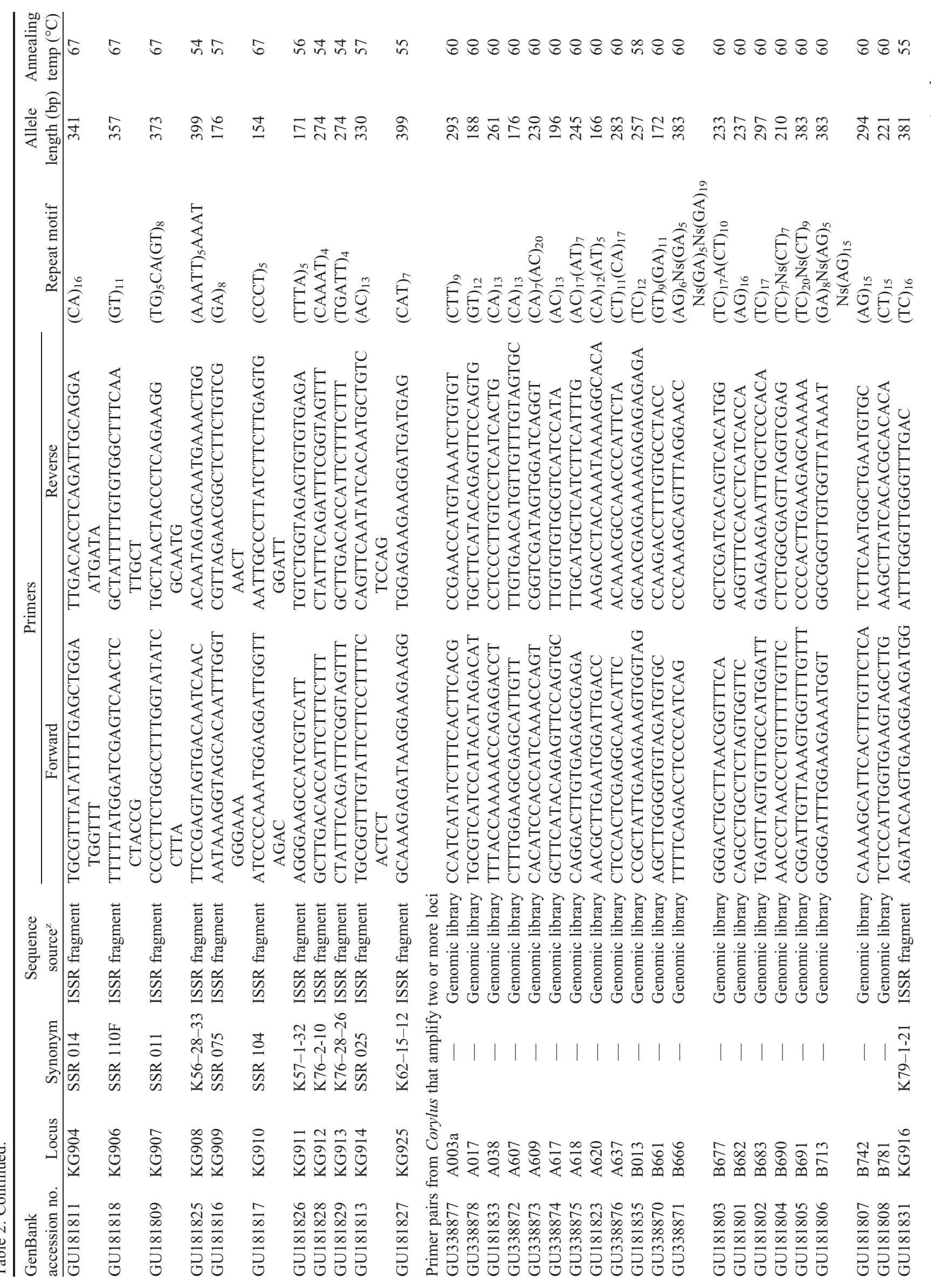




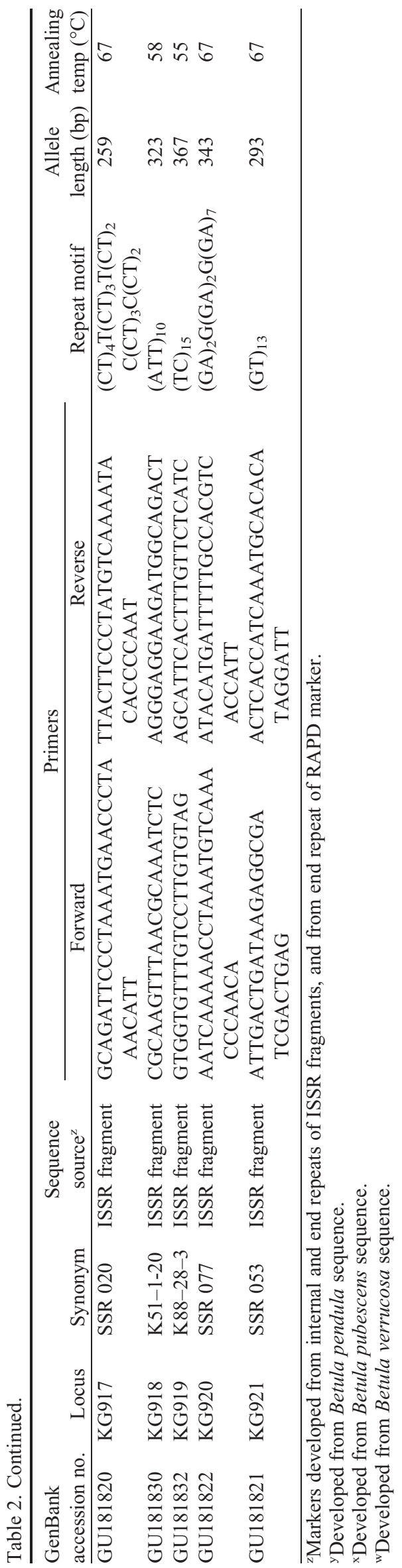

for 18 of the 36 primer pairs, but eight of these were monomorphic and four produced several bands over a large size range. The remaining six were polymorphic and single locus, and were characterized using $50 \mathrm{C}$. avellana accessions. Five of the six were polymorphic in our mapping population and were assigned to linkage groups (Table 4). For the 12 loci that were single-locus and polymorphic in Corylus (six published Betula loci, four new loci developed from Betula sequences, and two newly developed from a Corylus sequence), one primer of each pair was fluorescently labeled and used to amplify 50 hazelnut accessions. For the 10 Betula loci, mean values for $\mathrm{H}_{\mathrm{e}}, \mathrm{H}_{\mathrm{o}}$, and PIC were $0.66,0.53$, and 0.62 , respectively (Table 3 ). For the two Corylus loci, mean values for $\mathrm{H}_{\mathrm{e}}, \mathrm{H}_{\mathrm{o}}$, and PIC were 0.88 , 0.48 , and 0.47 , respectively (Table 3 ). A total of 78 alleles was produced at the 10 Betula loci (Table 3). The number of alleles ranged from 2 to 12 , with a mean of 8.58. A total of 29 alleles was produced at the two Corylus loci (Table 3). A high frequency of null alleles was observed at Betula locus CD277232 and Corylus locus AJ417975c.

Eight of the 10 Betula and one of the two Corylus markers segregated in the mapping population and were assigned to a linkage group (LG) based on cosegregation with existing markers (Mehlenbacher et al., 2006) (Table 4). AJ490266 showed a deficiency of 224/224 homozygotes, but the other seven loci showed good fit to Mendelian expectation.

The Betula genetic map of Pekkinen et al. (2005) includes 16 microsatellite markers of which we were able to map four (L5.5, L13.1, L7.8, and L1.10) in hazelnut. Three (BL55, BL131, and BL78) that were placed on LG2 in B. pendula were assigned to LG10 in hazelnut. BLK110 on LG5 in Betula was assigned to LG2 in Corylus. Of the remaining loci mapped in Betula by Pekkinen et al. (2005), three (L7.1, L5.4, and L3.1) amplified in hazelnut but were not polymorphic, five (L7.4, L7.3, L63, L3.4, and L2.2) failed to amplify in Corylus, and three (L2.3, L3.3, and L52) were not included in this study due to their low PIC values $(\leq 0.5)$. We were not able to map AG164 from Alnus because it was not polymorphic in our mapping population. SSR locus AJ417975b from the Corylus Lox gene was assigned to hazelnut LG7. Lipoxygenases (LOXs) are a class of dioxygenases that have diverse functions in several physiological processes such as growth, development, and response to biotic and abiotic stresses (Santino et al., 2003).

The locus AJ490266, developed from the Betula gene BpMADS2, was assigned to hazelnut LG7. BpMADS2 is similar to PISTILLATA (PI) from Arabidopsis thaliana and GLOBOSA (GLO) from Antirrhinum majus. They are homeotic B-function genes for the specification of the identity of petals and stamens (Järvinen et al., 2003). Locus Z72433, developed from the major Betula pollen allergen BetV 1 (Hoffmann-Sommergruber et al., 1997), was placed on hazelnut LG1.

Hazelnut pollen and food allergies are common in humans. In Europe, $0.1 \%$ to $0.5 \%$ of the population shows an allergic reaction to hazelnut pollen. Allergens from Corylus and Betula have been identified and characterized at the molecular and biochemical level (Lüttkopf et al., 2001; Schocker et al., 2002). Several forms of the hazelnut allergen have been sequenced, including Cor a 1.04, Cor a 1.01, Cor a 2, Cor a 8, Cor a 9, and Cor a 11. The hazelnut pollen allergens are similar to the major Betula pollen allergen Bet v 1 (Swoboda et al., 1995), which is a homolog of Cor a 1.04 .

Transferability of Betula and AlNus SSR PRIMER Pairs. The amplification ability of 52 SSR primer pairs from Betula 
Table 3. Characteristics of new polymorphic SSR loci from Betula and Corylus sequences based on amplification of 50 Corylus avellana accessions.

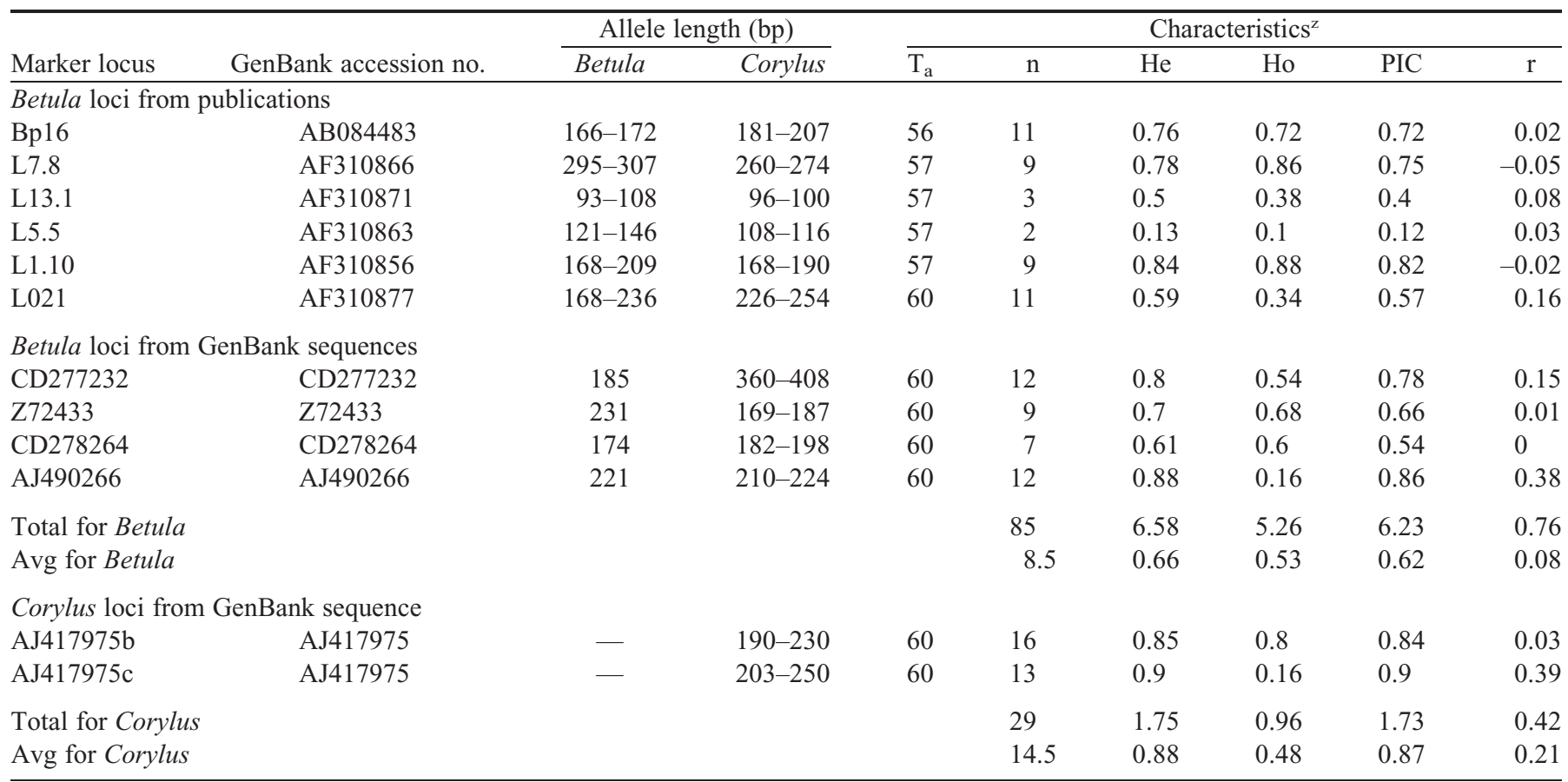

${ }^{\mathrm{z}} \mathrm{Ta}=$ annealing temperature $\left({ }^{\circ} \mathrm{C}\right), \mathrm{n}=$ number of alleles, $\mathrm{He}=$ expected heterozygosity, Ho $=$ observed heterozygosity, PIC $=$ polymorphism information content, $\mathrm{r}=$ null allele frequency.

Table 4. Segregation at nine SSR loci developed from database sequences and linkage group assignments.

\begin{tabular}{|c|c|c|c|c|c|c|c|}
\hline Locus & Species source & Allele sizes $[\times \widehat{\jmath}(\mathrm{bp})]$ & Observed ratio & Expected ratio & Chi-square & $P$ & Linkage group $^{z}$ \\
\hline AJ490266 & Betula pendula & $210 / 224 \times 224 / 224$ & $86: 57$ & $1: 1$ & 5.88 & $0.015^{y}$ & 7 \\
\hline BL131 & B. pendula & $99 / 99 \times 99 / 101$ & $61: 83$ & $1: 1$ & 3.36 & 0.07 & 10 \\
\hline CD277232 & B. pendula & $390 / 405 \times 396 / 396$ & $72: 68$ & $1: 1$ & 0.11 & 0.74 & 3 \\
\hline BLK110 & B. pendula & $175 / 190 \times 177 / 183$ & $38: 39: 29: 37$ & $1: 1: 1: 1$ & 1.76 & 0.62 & 2 \\
\hline BL78 & B. pendula & $260 / 268 \times 264 / 272$ & $39: 44: 29: 30$ & $1: 1: 1: 1$ & 4.42 & 0.22 & 10 \\
\hline
\end{tabular}

${ }^{\mathrm{z}}$ Linkage group assignments based on cosegregation with the markers of Mehlenbacher et al., (2006).

${ }^{\mathrm{y}}$ Observed segregation deviates from expected Mendelian ratios.

and two primer pairs from Alnus was investigated using 69 accessions of the Betulaceae (Table 5). Amplification of Betula accessions with individual SSR primer pairs ranged from $40 \%$ to $100 \%$, and exceeded $80 \%$ for 44 of the 52 primer pairs. Amplification using Betula primer pairs averaged $92.3 \%$ in Betula, $50.6 \%$ in Alnus, $41.2 \%$ in Corylus, $36.5 \%$ in Carpinus, $34.0 \%$ in Ostrya and $34.6 \%$ in Ostryopsis. Average amplification in the five other genera was $41.6 \%$, and the overall average in the six genera was $56.3 \%$. Amplification of Corylus accessions exceeded $80 \%$ at 14 of the 52 Betula SSR primer pairs. These values represent a useful level of transferability of Betula SSR primer pairs across the Betulaceae. Of the two primer pairs from Alnus, amplification with AGAG164a was excellent overall, while AGAG164b was successful only in nine of the 10 Alnus accessions.

Transferability OF BETULA SSR PRIMER PAIRS COMPARED BY ORIGIN. The 52 Betula SSR primer pairs studied include 2 from gene sequences, 10 from expressed sequence tags (ESTs), and 40 from genomic sequences. Z72433 developed from the Bet $v$
1 gene sequence amplified all accessions in all genera. AJ490266 developed from the MADS2 gene amplified 100\% of the Betula accessions and $94 \%$ of the accessions in other genera. These values indicate that the sequences of Bet $v 1$ and MADS2 are highly conserved in the Betulaceae. The 10 primer pairs developed from EST sequences amplified $70 \%$ to $100 \%$ of the Betula accessions and $0 \%$ to $86 \%$ of the accessions in other genera. The 40 primer pairs from genomic sequences amplified $40 \%$ to $100 \%$ of the Betula accessions and $0 \%$ to $100 \%$ of the accessions in other genera.

Transferability of Corylus SSR PRIMER PaIRs. The transferability of Corylus primer pairs was investigated with two sets of templates. The full set of 69 Betulaceae accessions was used to study transferability of 75 Corylus primer pairs (Table 5), and a subset of 32 accessions was used to study an additional 147 Corylus primer pairs (Table 6). For the 75 primer pairs used to amplify 69 accessions, average amplification was $81.4 \%$ in Corylus, $54.5 \%$ in Carpinus, $52.9 \%$ in Ostrya, $51.3 \%$ in Ostryopsis, $40.5 \%$ in Alnus, and $38.9 \%$ in Betula. Average 
Table 5. Amplification of 69 accessions of the Betulaceae using microsatellite markers developed from Betula, Alnus, and Corylus sequences.

\begin{tabular}{|c|c|c|c|c|c|c|c|c|c|c|}
\hline \multirow[b]{2}{*}{ Locus } & \multirow[b]{2}{*}{$\begin{array}{c}\text { GenBank } \\
\text { accession no. }\end{array}$} & \multicolumn{6}{|c|}{ Accessions amplified by genus (no.) } & \multicolumn{3}{|c|}{ Amplification (\%) } \\
\hline & & $\begin{array}{c}\text { Alnus } \\
(\mathrm{n}=10)\end{array}$ & $\begin{array}{c}\text { Betula } \\
(\mathrm{n}=20)\end{array}$ & $\begin{array}{l}\text { Corylus } \\
(\mathrm{n}=26)\end{array}$ & $\begin{array}{c}\text { Carpinus } \\
(\mathrm{n}=8)\end{array}$ & $\begin{array}{l}\text { Ostrya } \\
(\mathrm{n}=3)\end{array}$ & $\begin{array}{c}\text { Ostryopsis } \\
(\mathrm{n}=2)\end{array}$ & in Betula & $\begin{array}{c}\text { in other } \\
\text { genera }\end{array}$ & Total \\
\hline \multicolumn{11}{|c|}{ Markers from Betula database sequences (52) } \\
\hline Bp01 & AB084473 & 9 & 20 & 0 & 1 & 0 & 0 & 100 & 20.41 & 43.48 \\
\hline Bp04 & AB084474 & 10 & 20 & 13 & 7 & 3 & 0 & 100 & 67.35 & 76.81 \\
\hline Bp07 & $\mathrm{AB} 084475$ & 10 & 17 & 20 & 8 & 2 & 1 & 85 & 83.67 & 84.06 \\
\hline BpTA & AB084476 & 0 & 20 & 2 & 3 & 0 & 0 & 100 & 10.20 & 36.23 \\
\hline Bp10 & AB084477 & 0 & 20 & 3 & 0 & 1 & 0 & 100 & 8.2 & 34.8 \\
\hline Bp11 & AB084478 & 10 & 20 & 0 & 0 & 0 & 0 & 100 & 20.41 & 43.48 \\
\hline Bp13 & AB084480 & 0 & 18 & 0 & 0 & 0 & 0 & 90 & 0.00 & 26.09 \\
\hline Bp15 & AB084482 & 0 & 19 & 0 & 0 & 0 & 0 & 95 & 0.00 & 27.54 \\
\hline Bp16 & AB084483 & 10 & 20 & 24 & 7 & 3 & 2 & 100 & 93.88 & 95.65 \\
\hline $\mathrm{BpA}$ & AB084484 & 2 & 19 & 7 & 0 & 0 & 0 & 95 & 18.37 & 40.58 \\
\hline $\operatorname{Bmax} 544$ & AB094098 & 5 & 20 & 26 & 7 & 2 & 2 & 100 & 85.71 & 89.86 \\
\hline Bmax624 & AB094100 & 9 & 20 & 26 & 4 & 0 & 0 & 100 & 79.59 & 85.51 \\
\hline Bmax630 & AB094101 & 8 & 20 & 25 & 3 & 1 & 0 & 100 & 75.51 & 82.61 \\
\hline Bmax671 & AB094102 & 0 & 13 & 1 & 0 & 0 & 0 & 65 & 2.04 & 20.29 \\
\hline Bmax097 & AB094104 & 9 & 20 & 26 & 8 & 3 & 2 & 100 & 97.96 & 98.55 \\
\hline $\mathrm{L} 2.2$ & AF310846 & 0 & 20 & 0 & 0 & 1 & 0 & 100 & 2.04 & 30.43 \\
\hline $\mathrm{L} 2.5$ & AF310848 & 9 & 20 & 0 & 1 & 0 & 2 & 100 & 24.49 & 46.38 \\
\hline L2.7 & AF310850 & 7 & 20 & 18 & 5 & 3 & 2 & 100 & 71.43 & 79.71 \\
\hline L3.1 & AF310851 & 8 & 20 & 20 & 6 & 2 & 2 & 100 & 77.55 & 84.06 \\
\hline L3.4 & AF310852 & 7 & 20 & 6 & 4 & 0 & 1 & 100 & 36.73 & 55.07 \\
\hline L7.1 & AF310854 & 10 & 20 & 25 & 6 & 3 & 2 & 100 & 93.88 & 95.65 \\
\hline L7.4 & AF310855 & 0 & 17 & 0 & 0 & 0 & 0 & 85 & 0.00 & 24.64 \\
\hline L1.10 & AF310856 & 10 & 20 & 23 & 8 & 3 & 2 & 100 & 93.88 & 95.65 \\
\hline L4.4 & AF310858 & 0 & 12 & 1 & 0 & 0 & 0 & 60 & 2.04 & 18.84 \\
\hline- & AF310860 & 5 & 8 & 15 & 1 & 0 & 0 & 40 & 42.86 & 42.03 \\
\hline L5.1 & AF310861 & 0 & 20 & 0 & 0 & 0 & 0 & 100 & 0.00 & 28.99 \\
\hline L5.4 & AF310862 & 9 & 20 & 20 & 5 & 2 & 2 & 100 & 77.55 & 84.06 \\
\hline L5.5 & AF310863 & 10 & 20 & 26 & 8 & 3 & 2 & 100 & 100.00 & 100.00 \\
\hline L7.3 & AF310864 & 1 & 14 & 0 & 0 & 0 & 0 & 70 & 2.04 & 21.74 \\
\hline L7.8 & AF310866 & 9 & 20 & 26 & 4 & 1 & 2 & 100 & 85.71 & 89.86 \\
\hline L13.1 & AF310871 & 9 & 20 & 25 & 7 & 3 & 2 & 100 & 93.88 & 95.65 \\
\hline L63 & AF310873 & 1 & 20 & 0 & 0 & 0 & 0 & 100 & 2.04 & 30.43 \\
\hline L022 & AF310874 & 9 & 20 & 0 & 1 & 0 & 0 & 100 & 20.41 & 43.48 \\
\hline L021 & AF310877 & 0 & 19 & 21 & 2 & 0 & 0 & 95 & 46.94 & 60.87 \\
\hline - & AJ490266 & 10 & 20 & 26 & 8 & 3 & 2 & 100 & 100.00 & 100.00 \\
\hline Bo.F394 & AY423608 & 1 & 19 & 5 & 1 & 0 & 0 & 95 & 14.29 & 37.68 \\
\hline Bo.F330 & AY423611 & 10 & 20 & 26 & 8 & 3 & 2 & 100 & 100.00 & 100.00 \\
\hline - & AY423613 & 1 & 20 & 0 & 0 & 0 & 0 & 100 & 2.04 & 30.43 \\
\hline- & AY423614 & 0 & 15 & 0 & 0 & 0 & 0 & 75 & 0.00 & 21.74 \\
\hline Bo.G182 & AY423617 & 8 & 20 & 26 & 7 & 3 & 2 & 100 & 93.88 & 95.65 \\
\hline - & AY423621 & 1 & 18 & 0 & 0 & 0 & 0 & 90 & 2.04 & 27.54 \\
\hline- & CD276757 & 0 & 16 & 0 & 0 & 0 & 0 & 80 & 0.00 & 23.19 \\
\hline- & CD276825 & 0 & 17 & 0 & 0 & 0 & 0 & 85 & 0.00 & 24.64 \\
\hline- & CD276827 & 3 & 15 & 0 & 0 & 0 & 0 & 75 & 6.12 & 26.09 \\
\hline- & CD277232 & 4 & 20 & 7 & 3 & 1 & 0 & 100 & 30.61 & 50.72 \\
\hline- & CD277302 & 5 & 20 & 22 & 5 & 1 & 0 & 100 & 67.35 & 76.81 \\
\hline- & CD277382 & 6 & 14 & 0 & 0 & 0 & 0 & 70 & 12.2 & 29.0 \\
\hline- & CD278084 & 0 & 19 & 0 & 0 & 0 & 0 & 95 & 0.00 & 27.54 \\
\hline- & CD278264 & 9 & 18 & 22 & 6 & 3 & 2 & 90 & 85.71 & 86.96 \\
\hline- & CD278733 & 9 & 18 & 0 & 1 & 0 & 0 & 90 & 20.41 & 40.58 \\
\hline- & CD278994 & 0 & 15 & 0 & 0 & 0 & 0 & 75 & 0.00 & 21.74 \\
\hline - & Z72433 & 10 & 20 & 24 & 7 & 3 & 2 & 100 & 93.88 & 95.65 \\
\hline Mean of 5 & oci (no.) & 5.06 & 18.46 & 10.71 & 2.92 & 1.02 & 0.69 & 18.46 & 20.40 & 38.87 \\
\hline Mean of 5 & oci (\%) & 50.6 & 92.3 & 41.2 & 36.5 & 34.0 & 34.6 & 92.3 & 41.6 & 56.3 \\
\hline
\end{tabular}




\begin{tabular}{|c|c|c|c|c|c|c|c|c|c|c|}
\hline \multirow[b]{2}{*}{ Locus } & \multirow[b]{2}{*}{$\begin{array}{c}\text { GenBank } \\
\text { accession no. }\end{array}$} & \multicolumn{6}{|c|}{ Accessions amplified by genus (no.) } & \multicolumn{3}{|c|}{ Amplification (\%) } \\
\hline & & $\begin{array}{c}\text { Alnus } \\
(\mathrm{n}=10)\end{array}$ & $\begin{array}{c}\text { Betula } \\
(\mathrm{n}=20)\end{array}$ & $\begin{array}{l}\text { Corylus } \\
(\mathrm{n}=26)\end{array}$ & $\begin{array}{c}\text { Carpinus } \\
(\mathrm{n}=8)\end{array}$ & $\begin{array}{l}\text { Ostrya } \\
(\mathrm{n}=3)\end{array}$ & $\begin{array}{c}\text { Ostryopsis } \\
(\mathrm{n}=2)\end{array}$ & in $A \operatorname{lnus}$ & $\begin{array}{c}\text { in other } \\
\text { genera }\end{array}$ & Total \\
\hline \multicolumn{11}{|c|}{ Markers from Alnus database sequences } \\
\hline AGAG164a & Y08436 & 10 & 19 & 26 & 8 & 3 & 2 & 100 & 98.3 & 98.6 \\
\hline AGAG164b & Y08436 & 9 & 0 & 0 & 0 & 0 & 0 & 90 & 0.0 & 13.0 \\
\hline Mean of two & (no.) & 9.5 & 9.5 & 13 & 4 & 1.5 & 1 & & & \\
\hline Mean of two & $(\%)$ & 95.0 & 47.5 & 50.0 & 50.0 & 50.0 & 50.0 & 95.0 & 49.2 & 55.8 \\
\hline \multicolumn{11}{|c|}{ Markers from Corylus database sequences } \\
\hline AJ417975b & AJ417975 & 1 & 0 & 20 & 0 & 0 & 0 & 76.9 & 2.3 & 30.4 \\
\hline AJ417975c & AJ417975 & 0 & 0 & 12 & 2 & 1 & 1 & 46.2 & 9.3 & 23.2 \\
\hline Mean of two & (no.) & 0.50 & 0.00 & 16.00 & 1.00 & 0.50 & 0.50 & & & \\
\hline Mean of two & $(\%)$ & 5.0 & 0 & 61.5 & 12.5 & 16.7 & 25.0 & 61.5 & 5.8 & 26.8 \\
\hline \multicolumn{11}{|c|}{ Markers from Corylus enriched genomic libraries } \\
\hline A014a & - & 1 & 0 & 23 & 6 & 3 & 2 & 88.5 & 27.9 & 50.7 \\
\hline A040 & - & 0 & 0 & 15 & 1 & 2 & 2 & 57.7 & 4.7 & 24.6 \\
\hline B005 & - & 10 & 19 & 26 & 8 & 3 & 2 & 100.0 & 97.7 & 98.6 \\
\hline B010 & - & 5 & 11 & 25 & 5 & 1 & 2 & 96.2 & 55.8 & 71.0 \\
\hline B028 & - & 4 & 0 & 26 & 2 & 0 & 0 & 100.0 & 14.0 & 46.4 \\
\hline B029b & - & 4 & 13 & 26 & 5 & 1 & 0 & 100.0 & 53.5 & 71.0 \\
\hline B105 & - & 6 & 0 & 20 & 1 & 0 & 0 & 76.9 & 20.9 & 42.0 \\
\hline B111 & - & 1 & 0 & 15 & 0 & 0 & 0 & 57.7 & 2.3 & 23.2 \\
\hline B502 & - & 1 & 4 & 25 & 6 & 1 & 0 & 96.2 & 27.9 & 53.6 \\
\hline B505 & - & 3 & 11 & 26 & 7 & 1 & 0 & 100.0 & 51.2 & 69.6 \\
\hline B507 & - & 10 & 13 & 26 & 8 & 3 & 2 & 100.0 & 83.7 & 89.9 \\
\hline B508 & - & 2 & 13 & 21 & 8 & 3 & 2 & 80.8 & 65.1 & 71.0 \\
\hline B602 & - & 7 & 20 & 26 & 8 & 2 & 2 & 100.0 & 90.7 & 94.2 \\
\hline B606 & - & 0 & 0 & 20 & 5 & 3 & 2 & 76.9 & 23.3 & 43.5 \\
\hline B613 & - & 2 & 2 & 25 & 2 & 0 & 0 & 96.2 & 14.0 & 44.9 \\
\hline B617 & - & 10 & 9 & 26 & 5 & 3 & 1 & 100.0 & 72.1 & 82.6 \\
\hline B619 & - & 10 & 9 & 26 & 6 & 3 & 2 & 100.0 & 74.4 & 84.1 \\
\hline B634 & - & 10 & 20 & 26 & 7 & 3 & 2 & 100.0 & 97.7 & 98.6 \\
\hline B641a & - & 0 & 20 & 25 & 1 & 3 & 0 & 92.3 & 55.8 & 69.6 \\
\hline B641b & - & 0 & 2 & 20 & 6 & 3 & 2 & 76.9 & 30.2 & 47.8 \\
\hline B648 & - & 6 & 13 & 26 & 6 & 0 & 0 & 100.0 & 58.1 & 73.9 \\
\hline B656 & - & 1 & 0 & 24 & 1 & 0 & 0 & 92.3 & 4.7 & 37.7 \\
\hline B657 & - & 0 & 16 & 26 & 3 & 0 & 2 & 100.0 & 48.8 & 68.1 \\
\hline B664 & - & 10 & 19 & 26 & 8 & 3 & 2 & 100.0 & 97.7 & 98.6 \\
\hline B665 & - & 6 & 9 & 25 & 2 & 1 & 2 & 96.2 & 46.5 & 65.2 \\
\hline B702a & - & 10 & 19 & 23 & 8 & 3 & 2 & 92.3 & 97.7 & 95.7 \\
\hline B709 & - & 10 & 15 & 26 & 8 & 3 & 2 & 100.0 & 88.4 & 92.8 \\
\hline B719 & - & 5 & 9 & 24 & 5 & 0 & 0 & 92.3 & 46.5 & 63.8 \\
\hline B720 & - & 9 & 1 & 26 & 6 & 3 & 1 & 100.0 & 46.5 & 66.7 \\
\hline B732 & - & 0 & 2 & 26 & 1 & 0 & 0 & 100.0 & 7.0 & 42.0 \\
\hline B733 & - & 3 & 5 & 24 & 3 & 3 & 0 & 88.5 & 27.9 & 50.7 \\
\hline B741 & - & 3 & 0 & 26 & 7 & 3 & 1 & 100.0 & 32.6 & 58.0 \\
\hline B749 & - & 0 & 19 & 26 & 1 & 0 & 1 & 100.0 & 48.8 & 68.1 \\
\hline B751 & - & 6 & 14 & 25 & 3 & 2 & 1 & 96.2 & 65.1 & 76.8 \\
\hline B753 & - & 0 & 2 & 22 & 1 & 1 & 0 & 84.6 & 9.3 & 37.7 \\
\hline B762 & - & 6 & 12 & 25 & 6 & 1 & 2 & 96.2 & 62.8 & 75.4 \\
\hline B773 & - & 3 & 5 & 24 & 3 & 3 & 0 & 92.3 & 32.6 & 55.1 \\
\hline B774 & - & 1 & 0 & 26 & 7 & 0 & 0 & 96.2 & 18.6 & 49.3 \\
\hline B776 & - & 4 & 11 & 26 & 6 & 2 & 2 & 100.0 & 60.5 & 75.4 \\
\hline B779 & - & 3 & 14 & 26 & 8 & 3 & 2 & 100.0 & 67.4 & 79.7 \\
\hline B789 & - & 4 & 11 & 26 & 8 & 2 & 2 & 100.0 & 62.8 & 76.8 \\
\hline B791 & - & 5 & 1 & 24 & 3 & 2 & 2 & 92.3 & 30.2 & 53.6 \\
\hline B793 & - & 9 & 20 & 26 & 7 & 3 & 0 & 100.0 & 93.0 & 95.7 \\
\hline $\mathrm{C} 028$ & - & 7 & 13 & 26 & 8 & 3 & 2 & 100.0 & 76.7 & 85.5 \\
\hline
\end{tabular}


Table 5. Continued.

\begin{tabular}{|c|c|c|c|c|c|c|c|c|c|c|}
\hline \multirow[b]{2}{*}{ Locus } & \multirow[b]{2}{*}{$\begin{array}{c}\text { GenBank } \\
\text { accession no. }\end{array}$} & \multicolumn{6}{|c|}{ Accessions amplified by genus (no.) } & \multicolumn{3}{|c|}{ Amplification (\%) } \\
\hline & & $\begin{array}{c}\text { Alnus } \\
(\mathrm{n}=10)\end{array}$ & $\begin{array}{c}\text { Betula } \\
(\mathrm{n}=20)\end{array}$ & $\begin{array}{l}\text { Corylus } \\
(\mathrm{n}=26)\end{array}$ & $\begin{array}{c}\text { Carpinus } \\
(\mathrm{n}=8)\end{array}$ & $\begin{array}{l}\text { Ostrya } \\
(\mathrm{n}=3)\end{array}$ & $\begin{array}{c}\text { Ostryopsis } \\
(\mathrm{n}=2)\end{array}$ & in $A \operatorname{lnu} s$ & $\begin{array}{l}\text { in other } \\
\text { genera }\end{array}$ & Total \\
\hline$\overline{\mathrm{C} 040}$ & - & 4 & 14 & 25 & 6 & 3 & 2 & 96.2 & 62.8 & 75.4 \\
\hline C118 & - & 10 & 19 & 22 & 5 & 3 & 2 & 84.6 & 90.7 & 88.4 \\
\hline C119 & - & 9 & 19 & 26 & 8 & 3 & 2 & 100.0 & 95.3 & 97.1 \\
\hline Mean of 59 loci $(\%)$ & & 39.2 & 40.0 & 77.9 & 53.0 & 52.5 & 50.0 & 77.8 & 43.7 & 56.6 \\
\hline \multicolumn{11}{|c|}{ Markers from Corylus internal repeats in ISSR fragments } \\
\hline KG802 & - & 3 & 11 & 23 & 5 & 1 & 0 & 88.5 & 46.5 & 62.3 \\
\hline KG803 & - & 10 & 19 & 26 & 8 & 2 & 2 & 100.0 & 95.3 & 97.1 \\
\hline KG806 & - & 2 & 2 & 26 & 8 & 2 & 0 & 100.0 & 32.6 & 58.0 \\
\hline KG813 & - & 4 & 9 & 26 & 4 & 2 & 1 & 100.0 & 44.2 & 65.2 \\
\hline KG815 & - & 10 & 6 & 25 & 7 & 2 & 2 & 96.2 & 62.8 & 75.4 \\
\hline KG816 & - & 2 & 7 & 26 & 6 & 3 & 1 & 100.0 & 44.2 & 65.2 \\
\hline KG817 & - & 8 & 6 & 26 & 3 & 0 & 0 & 100.0 & 39.5 & 62.3 \\
\hline KG819 & - & 0 & 1 & 26 & 5 & 2 & 1 & 100.0 & 20.9 & 50.7 \\
\hline KG821 & - & 7 & 0 & 26 & 7 & 2 & 2 & 100.0 & 41.9 & 63.8 \\
\hline KG822 & - & 0 & 0 & 26 & 0 & 0 & 0 & 100.0 & 0.0 & 37.7 \\
\hline \multicolumn{2}{|l|}{ Mean of 14 loci (no.) } & 5.14 & 8.00 & 25.71 & 5.36 & 1.79 & 1.21 & & & \\
\hline \multicolumn{2}{|c|}{ Mean of 14 loci (\%) } & 51.4 & 40.0 & 98.9 & 67.0 & 59.5 & 60.7 & 98.9 & 50.0 & 68.4 \\
\hline \multicolumn{2}{|c|}{ Mean of 75 Corylus loci (\%) } & 40.5 & 38.9 & 81.4 & 54.5 & 52.9 & 51.3 & 81.4 & 43.8 & 57.9 \\
\hline
\end{tabular}

amplification of other genera was $43.8 \%$, and the overall average was $57.9 \%$. Amplification of Corylus accessions at individual SSR primer pairs ranged from $46.2 \%$ to $100 \%$, and was lower in the two primer pairs developed from the Lox gene sequence than from enriched libraries or ISSR fragments. Amplification of Corylus exceeded $80 \%$ at 57 of the 75 primer pairs. Over all 69 accessions, amplification exceeded $80 \%$ at 17 of the 75 primer pairs. For the two SSR primer pairs developed from the Corylus lox gene (AJ417975b and AJ417975c), amplification was $76.9 \%$ and $46.2 \%$ in Corylus accessions, and $2.3 \%$ and $4.6 \%$ in accessions of other genera, respectively.

For the 147 Corylus primer pairs used to amplify the subset of 32 accessions (Table 6), average amplification was 91.9\% in Corylus, $32.9 \%$ in Carpinus, 32.7\% in Ostrya, $43.9 \%$ in Ostryopsis, 34.9\% in Alnus, and 53.9\% in Betula. Average amplification of other genera was $43.0 \%$, and the overall average was $58.3 \%$. In genera other than Corylus, average amplification at polymorphic primer pairs developed from enriched libraries $(33.2 \%)$ was lower than for polymorphic primer pairs developed from ISSR sequences, monomorphic primer pairs, and primer pairs that amplified more than one locus. Amplification exceeded $80 \%$ at 127 of the 147 primer pairs in Corylus, and at 34 of the primer pairs in other genera. As with the Betula SSR primer pairs, the values for these two sets of Corylus primer pairs represent a useful level of transferability across the Betulaceae.

As expected, amplification was higher in species of the genus from which the SSR locus was developed than in the other genera. The Betula primer pairs amplified $92.3 \%$ of the Betula accessions and $41.2 \%$ of the Corylus accessions. The first set of Corylus primer pairs amplified $80.8 \%$ of the Corylus accessions and $38.4 \%$ of the Betula accessions. The second set of Corylus primer pairs amplified $91.9 \%$ of the Corylus accessions and $53.9 \%$ of the Betula accessions. Recent comparative genomic research has shown that despite vast diversity in angiosperms, plants have retained homologous genes with the same or very similar function during evolution. Homoeologous chromosomes in allopolyploid species and the chromosomes of closely related diploid species are extensively conserved (Bennetzen, 2000; Paterson et al., 2007). Comparisons of related species have shown gene synteny and marker colinearity with some chromosome rearrangements through translocation or inversions. Varshney et al. (2005) found that of 165 barley (Hordeum vulgare) EST-SSR loci studied, 78.2\% showed amplification in wheat, followed by $75.2 \%$ in rye (Secale cereale), and $42.4 \%$ in rice (Oryza sativa). Heesacker et al. (2008) also reported that $88.6 \%$ of the 466 sunflower (Helianthus annuus) EST-SSR or INDEL markers amplified alleles from one or more wild species, whereas $14.8 \%$ amplified alleles from distantly related safflower (Carthamus tinctorius), and 14.4\% amplified alleles from lettuce (Lactuca sativa), a distantly related genus in the Asteraceae. Dirlewanger et al. (2004) compared maps for Prunus and Malus using 30 homologous SSR markers. Barbara et al. (2007) reviewed 64 microsatellite marker transferability studies and found an average cross-species transferability success rate of about $60 \%$ in eudicots and about $40 \%$ in monocots, whereas between genera, it was only $\approx 10 \%$ for eudicots. Our results show high transferability $(38 \%-54 \%)$ in the Betulaceae that is unaffected by the polyploidy of some Betula accessions. 
Table 6. Amplification of 32 Betulaceae accessions at 147 microsatellite loci from Corylus.

\begin{tabular}{|c|c|c|c|c|c|c|c|c|c|}
\hline \multirow[b]{2}{*}{ Locus } & \multicolumn{6}{|c|}{ Accessions amplified by genus (no.) } & \multicolumn{3}{|c|}{ Amplification (\%) in } \\
\hline & $\begin{array}{c}\text { Alnus } \\
(\mathrm{n}=6)\end{array}$ & $\begin{array}{l}\text { Betula } \\
(\mathrm{n}=9)\end{array}$ & $\begin{array}{l}\text { Corylus } \\
(\mathrm{n}=10)\end{array}$ & $\begin{array}{c}\text { Carpinus } \\
(\mathrm{n}=3)\end{array}$ & $\begin{array}{l}\text { Ostrya } \\
(\mathrm{n}=2)\end{array}$ & $\begin{array}{c}\text { Ostryopsis } \\
(\mathrm{n}=2)\end{array}$ & Corylus & $\begin{array}{c}\text { Other } \\
\text { Genera }\end{array}$ & Total \\
\hline \multicolumn{10}{|c|}{ Polymorphic loci from enriched libraries $(n=54)$} \\
\hline $\mathrm{A} 024 \mathrm{~b}$ & 0 & 6 & 7 & 0 & 0 & 0 & 70 & 27.3 & 40.6 \\
\hline A036 & 6 & 9 & 8 & 3 & 2 & 2 & 80 & 100.0 & 93.8 \\
\hline A601 & 0 & 2 & 10 & 0 & 0 & 1 & 100 & 13.6 & 40.6 \\
\hline A602 & 2 & 0 & 10 & 3 & 0 & 0 & 100 & 22.7 & 46.9 \\
\hline A604 & 6 & 8 & 10 & 3 & 2 & 2 & 100 & 95.5 & 96.9 \\
\hline A605 & 1 & 9 & 10 & 0 & 0 & 0 & 100 & 45.5 & 62.5 \\
\hline A606 & 1 & 0 & 8 & 0 & 2 & 0 & 80 & 13.6 & 34.4 \\
\hline A611 & 1 & 4 & 10 & 0 & 0 & 1 & 100 & 27.3 & 50.0 \\
\hline A613 & 4 & 9 & 10 & 3 & 2 & 2 & 100 & 90.9 & 93.8 \\
\hline A614 & 4 & 9 & 10 & 0 & 0 & 0 & 100 & 59.1 & 71.9 \\
\hline A616 & 6 & 7 & 10 & 3 & 2 & 2 & 100 & 90.9 & 93.8 \\
\hline A635 & 0 & 0 & 10 & 0 & 0 & 0 & 100 & 0.0 & 31.3 \\
\hline A640 & 0 & 3 & 10 & 0 & 0 & 0 & 100 & 13.6 & 40.6 \\
\hline B001 & 6 & 0 & 10 & 0 & 0 & 1 & 100 & 31.8 & 53.1 \\
\hline B501 & 0 & 1 & 10 & 0 & 1 & 1 & 100 & 13.6 & 40.6 \\
\hline B603 & 0 & 9 & 9 & 0 & 0 & 0 & 90 & 40.9 & 56.3 \\
\hline B604 & 6 & 0 & 9 & 3 & 1 & 2 & 90 & 54.5 & 65.6 \\
\hline B608 & 0 & 0 & 8 & 0 & 1 & 0 & 80 & 4.5 & 28.1 \\
\hline B628 & 0 & 7 & 10 & 0 & 0 & 1 & 100 & 36.4 & 56.3 \\
\hline B629 & 0 & 0 & 10 & 0 & 0 & 0 & 100 & 0.0 & 31.3 \\
\hline B631 & 6 & 9 & 10 & 3 & 2 & 2 & 100 & 100.0 & 100.0 \\
\hline B635 & 0 & 6 & 10 & 3 & 1 & 0 & 100 & 45.5 & 62.5 \\
\hline B639 & 1 & 9 & 9 & 2 & 1 & 1 & 90 & 63.6 & 71.9 \\
\hline B640 & 1 & 7 & 9 & 0 & 0 & 0 & 90 & 36.4 & 53.1 \\
\hline B643 & 0 & 8 & 9 & 0 & 0 & 0 & 90 & 36.4 & 53.1 \\
\hline B651 & 0 & 0 & 10 & 0 & 1 & 1 & 100 & 9.1 & 37.5 \\
\hline B652 & 0 & 1 & 10 & 0 & 0 & 0 & 100 & 4.5 & 34.4 \\
\hline B654 & 1 & 0 & 10 & 0 & 0 & 1 & 100 & 9.1 & 37.5 \\
\hline B655 & 0 & 0 & 10 & 0 & 0 & 0 & 100 & 0.0 & 31.3 \\
\hline B660 & 6 & 9 & 10 & 0 & 0 & 1 & 100 & 72.7 & 81.3 \\
\hline B662 & 1 & 9 & 10 & 0 & 0 & 0 & 100 & 45.5 & 62.5 \\
\hline B667 & 0 & 0 & 7 & 0 & 0 & 0 & 70 & 0.0 & 21.9 \\
\hline B670 & 0 & 1 & 10 & 0 & 0 & 0 & 100 & 4.5 & 34.4 \\
\hline B671 & 1 & 3 & 10 & 0 & 0 & 1 & 100 & 22.7 & 46.9 \\
\hline B686 & 4 & 9 & 5 & 1 & 2 & 1 & 50 & 77.3 & 68.8 \\
\hline B701 & 6 & 9 & 9 & 0 & 2 & 2 & 90 & 86.4 & 87.5 \\
\hline B706 & 0 & 9 & 8 & 2 & 2 & 2 & 80 & 68.2 & 71.9 \\
\hline B716 & 0 & 0 & 10 & 0 & 0 & 0 & 100 & 0.0 & 31.3 \\
\hline B726 & 0 & 5 & 8 & 0 & 0 & 0 & 80 & 22.7 & 40.6 \\
\hline B728 & 0 & 0 & 9 & 0 & 0 & 1 & 90 & 4.5 & 31.3 \\
\hline B734 & 2 & 3 & 10 & 0 & 1 & 0 & 100 & 27.3 & 50.0 \\
\hline B735 & 6 & 9 & 7 & 3 & 2 & 2 & 70 & 100.0 & 90.6 \\
\hline B737 & 0 & 0 & 9 & 0 & 0 & 0 & 90 & 0.0 & 28.1 \\
\hline B738 & 0 & 0 & 10 & 0 & 0 & 0 & 100 & 0.0 & 31.3 \\
\hline B760 & 0 & 0 & 10 & 0 & 0 & 0 & 100 & 0.0 & 31.3 \\
\hline B761 & 0 & 0 & 10 & 0 & 0 & 0 & 100 & 0.0 & 31.3 \\
\hline B767 & 0 & 8 & 9 & 0 & 0 & 0 & 90 & 36.4 & 53.1 \\
\hline B768 & 1 & 1 & 10 & 0 & 0 & 1 & 100 & 13.6 & 40.6 \\
\hline B769 & 3 & 3 & 10 & 0 & 0 & 0 & 100 & 27.3 & 50.0 \\
\hline B770 & 0 & 0 & 10 & 0 & 0 & 0 & 100 & 0.0 & 31.3 \\
\hline B777 & 0 & 9 & 10 & 0 & 0 & 1 & 100 & 45.5 & 62.5 \\
\hline B788 & 2 & 4 & 9 & 0 & 0 & 0 & 90 & 27.3 & 46.9 \\
\hline B790 & 1 & 4 & 10 & 0 & 0 & 0 & 100 & 22.7 & 46.9 \\
\hline B795 & 0 & 0 & 10 & 0 & 0 & 0 & 100 & 0.0 & 31.3 \\
\hline
\end{tabular}


Table 6. Continued.

\begin{tabular}{|c|c|c|c|c|c|c|c|c|c|}
\hline \multirow[b]{2}{*}{ Locus } & \multicolumn{6}{|c|}{ Accessions amplified by genus (no.) } & \multicolumn{3}{|c|}{ Amplification $(\%)$ in } \\
\hline & $\begin{array}{l}\text { Alnus } \\
(\mathrm{n}=6)\end{array}$ & $\begin{array}{l}\text { Betula } \\
(\mathrm{n}=9)\end{array}$ & $\begin{array}{l}\text { Corylus } \\
(\mathrm{n}=10)\end{array}$ & $\begin{array}{c}\text { Carpinus } \\
(\mathrm{n}=3)\end{array}$ & $\begin{array}{l}\text { Ostrya } \\
(\mathrm{n}=2)\end{array}$ & $\begin{array}{c}\text { Ostryopsis } \\
(\mathrm{n}=2)\end{array}$ & Corylus & $\begin{array}{c}\text { Other } \\
\text { Genera }\end{array}$ & Total \\
\hline Mean (no.) & 1.6 & 4.0 & 9.4 & 0.6 & 0.5 & 0.6 & & & \\
\hline Mean (\%) & 26.2 & 44.9 & 93.7 & 19.8 & 25.0 & 29.6 & 93.7 & 33.2 & 52.1 \\
\hline \multicolumn{10}{|c|}{ Polymorphic loci from ISSR fragments $(\mathrm{n}=50)$} \\
\hline KG800 & 1 & 9 & 10 & 3 & 2 & 0 & 100 & 68.2 & 78.1 \\
\hline KG801 & 0 & 1 & 10 & 0 & 0 & 1 & 100 & 9.1 & 37.5 \\
\hline KG803 & 0 & 5 & 10 & 3 & 0 & 0 & 100 & 36.4 & 56.3 \\
\hline KG804 & 0 & 0 & 10 & 0 & 0 & 0 & 100 & 0.0 & 31.3 \\
\hline KG805 & 0 & 0 & 8 & 0 & 0 & 0 & 80 & 0.0 & 25.0 \\
\hline KG811 & 0 & 0 & 10 & 0 & 0 & 0 & 100 & 0.0 & 31.3 \\
\hline KG812 & 5 & 0 & 10 & 1 & 0 & 0 & 100 & 27.3 & 50.0 \\
\hline KG814 & 6 & 9 & 10 & 3 & 2 & 2 & 100 & 100.0 & 100.0 \\
\hline KG820 & 1 & 0 & 9 & 0 & 0 & 1 & 90 & 9.1 & 34.4 \\
\hline KG823 & 6 & 9 & 9 & 3 & 2 & 2 & 90 & 100.0 & 96.9 \\
\hline KG824 & 6 & 3 & 9 & 3 & 2 & 2 & 90 & 72.7 & 78.1 \\
\hline KG825 & 0 & 9 & 8 & 0 & 1 & 2 & 80 & 54.5 & 62.5 \\
\hline KG826 & 6 & 9 & 8 & 3 & 0 & 2 & 80 & 90.9 & 87.5 \\
\hline KG827 & 0 & 5 & 10 & 2 & 0 & 2 & 100 & 40.9 & 59.4 \\
\hline KG828 & 6 & 9 & 9 & 3 & 1 & 2 & 90 & 95.5 & 93.8 \\
\hline KG829 & 2 & 9 & 10 & 0 & 1 & 1 & 100 & 59.1 & 71.9 \\
\hline KG830 & 6 & 9 & 10 & 3 & 2 & 2 & 100 & 100.0 & 100.0 \\
\hline KG831 & 0 & 3 & 7 & 1 & 0 & 0 & 70 & 18.2 & 34.4 \\
\hline KG832 & 3 & 9 & 10 & 3 & 2 & 0 & 100 & 77.3 & 84.4 \\
\hline KG833 & 1 & 1 & 9 & 0 & 0 & 0 & 90 & 9.1 & 34.4 \\
\hline KG834 & 0 & 0 & 10 & 0 & 2 & 2 & 100 & 18.2 & 43.8 \\
\hline KG836 & 3 & 3 & 8 & 0 & 1 & 0 & 80 & 31.8 & 46.9 \\
\hline KG838 & 6 & 8 & 7 & 2 & 1 & 2 & 70 & 86.4 & 81.3 \\
\hline KG840 & 5 & 9 & 10 & 0 & 0 & 0 & 100 & 63.6 & 75.0 \\
\hline KG841 & 4 & 7 & 10 & 2 & 0 & 0 & 100 & 59.1 & 71.9 \\
\hline KG842 & 4 & 9 & 10 & 0 & 0 & 2 & 100 & 68.2 & 78.1 \\
\hline KG843 & 2 & 9 & 10 & 3 & 2 & 2 & 100 & 81.8 & 87.5 \\
\hline KG844 & 4 & 3 & 10 & 0 & 0 & 1 & 100 & 36.4 & 56.3 \\
\hline KG845 & 0 & 1 & 10 & 0 & 0 & 1 & 100 & 9.1 & 37.5 \\
\hline KG846 & 3 & 0 & 10 & 2 & 0 & 1 & 100 & 27.3 & 50.0 \\
\hline KG847 & 0 & 5 & 10 & 0 & 0 & 2 & 100 & 31.8 & 53.1 \\
\hline KG848 & 0 & 2 & 10 & 0 & 0 & 0 & 100 & 9.1 & 37.5 \\
\hline KG851 & 3 & 6 & 10 & 1 & 1 & 2 & 100 & 59.1 & 71.9 \\
\hline KG852 & 4 & 6 & 10 & 0 & 0 & 2 & 100 & 54.5 & 68.8 \\
\hline KG854 & 6 & 9 & 7 & 3 & 2 & 2 & 70 & 100.0 & 90.6 \\
\hline KG855 & 6 & 9 & 5 & 3 & 2 & 2 & 50 & 100.0 & 84.4 \\
\hline KG857 & 0 & 0 & 10 & 0 & 0 & 0 & 100 & 0.0 & 31.3 \\
\hline KG858 & 6 & 9 & 10 & 1 & 0 & 2 & 100 & 81.8 & 87.5 \\
\hline KG859 & 6 & 9 & 10 & 1 & 2 & 1 & 100 & 86.4 & 90.6 \\
\hline KG860 & 5 & 7 & 10 & 0 & 1 & 2 & 100 & 68.2 & 78.1 \\
\hline KG861 & 0 & 1 & 10 & 0 & 0 & 0 & 100 & 4.5 & 34.4 \\
\hline KG864 & 2 & 9 & 6 & 0 & 0 & 1 & 60 & 54.5 & 56.3 \\
\hline KG865 & 6 & 9 & 5 & 3 & 2 & 2 & 50 & 100.0 & 84.4 \\
\hline KG867 & 1 & 7 & 10 & 0 & 1 & 1 & 100 & 45.5 & 62.5 \\
\hline KG868 & 6 & 9 & 8 & 3 & 2 & 2 & 80 & 100.0 & 93.8 \\
\hline KG869 & 0 & 1 & 10 & 0 & 0 & 0 & 100 & 4.5 & 34.4 \\
\hline KG870 & 1 & 9 & 9 & 1 & 2 & 2 & 90 & 68.2 & 75.0 \\
\hline KG873 & 4 & 8 & 9 & 2 & 1 & 2 & 90 & 77.3 & 81.3 \\
\hline KG874 & 4 & 8 & 10 & 2 & 1 & 1 & 100 & 72.7 & 81.3 \\
\hline W07-SSR & 6 & 9 & 6 & 3 & 2 & 2 & 60 & 100.0 & 87.5 \\
\hline Mean (no.) & 2.9 & 5.6 & 9.1 & 1.3 & 0.8 & 1.2 & & & \\
\hline Mean (\%) & 48.7 & 62.2 & 91.2 & 42.0 & 40.0 & 58.0 & 91.2 & 53.4 & 65.2 \\
\hline
\end{tabular}


Table 6. Continued.

\begin{tabular}{|c|c|c|c|c|c|c|c|c|c|}
\hline \multirow[b]{2}{*}{ Locus } & \multicolumn{6}{|c|}{ Accessions amplified by genus (no.) } & \multicolumn{3}{|c|}{ Amplification $(\%)$ in } \\
\hline & $\begin{array}{l}\text { Alnus } \\
(\mathrm{n}=6)\end{array}$ & $\begin{array}{l}\text { Betula } \\
(\mathrm{n}=9)\end{array}$ & $\begin{array}{l}\text { Corylus } \\
(\mathrm{n}=10)\end{array}$ & $\begin{array}{c}\text { Carpinus } \\
(\mathrm{n}=3)\end{array}$ & $\begin{array}{l}\text { Ostrya } \\
(\mathrm{n}=2)\end{array}$ & $\begin{array}{c}\text { Ostryopsis } \\
(\mathrm{n}=2)\end{array}$ & Corylus & $\begin{array}{c}\text { Other } \\
\text { Genera }\end{array}$ & Total \\
\hline \multicolumn{10}{|c|}{ Loci monomorphic in Corylus avellana $(\mathrm{n}=17)$} \\
\hline B 620 & 0 & 0 & 10 & 3 & 0 & 2 & 100 & 22.7 & 46.9 \\
\hline $\mathrm{B} 702 \mathrm{~b}$ & 0 & 7 & 10 & 0 & 0 & 0 & 100 & 31.8 & 53.1 \\
\hline B747 & 6 & 9 & 6 & 0 & 1 & 0 & 60 & 72.7 & 68.8 \\
\hline SSR 011 & 0 & 2 & 10 & 0 & 1 & 1 & 100 & 18.2 & 43.8 \\
\hline SSR 014 & 0 & 9 & 10 & 0 & 0 & 0 & 100 & 40.9 & 59.4 \\
\hline SSR 022 & 3 & 9 & 10 & 1 & 2 & 2 & 100 & 77.3 & 84.4 \\
\hline SSR 025 & 2 & 3 & 8 & 1 & 0 & 1 & 80 & 31.8 & 46.9 \\
\hline SSR 064 & 3 & 9 & 10 & 3 & 2 & 2 & 100 & 86.4 & 90.6 \\
\hline SSR 075 & 0 & 0 & 10 & 0 & 0 & 2 & 100 & 9.1 & 37.5 \\
\hline SSR 104 & 0 & 1 & 10 & 0 & 0 & 0 & 100 & 4.5 & 34.4 \\
\hline SSR 110F & 1 & 4 & 10 & 0 & 1 & 1 & 100 & 31.8 & 53.1 \\
\hline K18-28-24 & 0 & 9 & 10 & 0 & 0 & 1 & 100 & 45.5 & 62.5 \\
\hline K56-28-33 & 0 & 2 & 10 & 0 & 0 & 0 & 100 & 9.1 & 37.5 \\
\hline K57-1-32 & 0 & 0 & 10 & 0 & 0 & 0 & 100 & 0.0 & 31.3 \\
\hline K62-15-12 & 0 & 9 & 7 & 0 & 0 & 1 & 70 & 45.5 & 53.1 \\
\hline K76-2-10 & 6 & 9 & 9 & 3 & 2 & 2 & 90 & 100.0 & 96.9 \\
\hline K76-28-26 & 6 & 9 & 8 & 3 & 2 & 2 & 80 & 100.0 & 93.8 \\
\hline Mean (no.) & 1.6 & 5.4 & 9.3 & 0.8 & 0.6 & 1.0 & & & \\
\hline Mean $(\%)$ & 26.5 & 59.5 & 92.9 & 27.5 & 32.4 & 50.0 & 92.9 & 42.8 & 58.5 \\
\hline \multicolumn{10}{|c|}{ Primer pairs that amplify two or more loci $(n=26)$} \\
\hline $\mathrm{A} 003 \mathrm{a}$ & 1 & 9 & 9 & 1 & 0 & 0 & 90 & 50.0 & 62.5 \\
\hline A017 & 0 & 1 & 7 & 0 & 0 & 0 & 70 & 4.5 & 25.0 \\
\hline A038 & 6 & 8 & 10 & 0 & 0 & 0 & 100 & 63.6 & 75.0 \\
\hline A607 & 0 & 1 & 10 & 0 & 0 & 0 & 100 & 4.5 & 34.4 \\
\hline A609 & 4 & 6 & 9 & 3 & 2 & 2 & 90 & 77.3 & 81.3 \\
\hline A617 & 0 & 0 & 10 & 0 & 0 & 0 & 100 & 0.0 & 31.3 \\
\hline A618 & 1 & 9 & 10 & 1 & 0 & 0 & 100 & 50.0 & 65.6 \\
\hline A620 & 0 & 2 & 6 & 2 & 0 & 0 & 60 & 18.2 & 31.3 \\
\hline A637 & 0 & 3 & 10 & 0 & 0 & 1 & 100 & 18.2 & 43.8 \\
\hline B013 & 0 & 0 & 10 & 0 & 1 & 0 & 100 & 4.5 & 34.4 \\
\hline B661 & 0 & 7 & 10 & 2 & 2 & 2 & 100 & 59.1 & 71.9 \\
\hline B666 & 6 & 9 & 5 & 3 & 2 & 2 & 50 & 100.0 & 84.4 \\
\hline B677 & 0 & 2 & 7 & 0 & 0 & 0 & 70 & 9.1 & 28.1 \\
\hline B682 & 5 & 4 & 9 & 3 & 2 & 2 & 90 & 72.7 & 78.1 \\
\hline B683 & 0 & 1 & 10 & 3 & 0 & 1 & 100 & 22.7 & 46.9 \\
\hline B690 & 0 & 2 & 10 & 2 & 0 & 1 & 100 & 22.7 & 46.9 \\
\hline B691 & 6 & 9 & 10 & 0 & 0 & 0 & 100 & 68.2 & 78.1 \\
\hline B713 & 0 & 1 & 10 & 1 & 0 & 1 & 100 & 13.6 & 40.6 \\
\hline B742 & 1 & 4 & 9 & 0 & 1 & 1 & 90 & 31.8 & 50.0 \\
\hline B781 & 0 & 9 & 6 & 3 & 2 & 2 & 60 & 72.7 & 68.8 \\
\hline SSR 020 & 5 & 9 & 10 & 3 & 2 & 2 & 100 & 95.5 & 96.9 \\
\hline SSR 053 & 2 & 3 & 7 & 1 & 0 & 0 & 70 & 27.3 & 40.6 \\
\hline SSR 077 & 1 & 8 & 7 & 3 & 0 & 2 & 70 & 63.6 & 65.6 \\
\hline K51-1-20 & 6 & 8 & 10 & 2 & 2 & 1 & 100 & 86.4 & 90.6 \\
\hline K79-1-21 & 6 & 9 & 10 & 3 & 2 & 2 & 100 & 100.0 & 100.0 \\
\hline K88-28-3 & 0 & 0 & 10 & 0 & 0 & 0 & 100 & 0.0 & 31.3 \\
\hline Mean (no.) & 1.9 & 4.8 & 8.9 & 1.4 & 0.7 & 0.8 & & & \\
\hline Mean $(\%)$ & 32.1 & 53.0 & 88.8 & 46.2 & 34.6 & 42.3 & 88.8 & 43.7 & 57.8 \\
\hline Overall mean (no.) & 2.1 & 4.9 & 9.2 & 1.0 & 0.7 & 0.9 & & & \\
\hline Overall mean (\%) & 34.9 & 53.9 & 91.9 & 32.9 & 32.7 & 43.9 & 91.9 & 43.0 & 58.3 \\
\hline
\end{tabular}

RELATIONSHIP OF TRANSFERABILITY AND TAXONOMY. Results of SSR transferability are in agreement with the generally accepted taxonomy of the Betulaceae. Traditionally, Betula- ceae is divided into two subfamilies, Betuloideae (Alnus and Betula) and Coryloideae (Corylus, Carpinus, Ostrya, and Ostryopsis) (Chen et al., 1999). The organelle sequences of 
Chen et al. (1999) support this classification. Betula species were studied by Järvinen et al. (2004) and Schenk et al. (2008), Alnus species by Chen and Li (2004) and Navarro et al. (2003), Carpinus by Yoo and Wen (2002), and Corylus by Erdoğan and Mehlenbacher (2000) and Forest and Bruneau (2000). Our results indicate better amplification within the subfamily of origin, and lower amplification in the other subfamily.

We developed 20 new SSR primer pairs from GenBank sequences of the Betulaceae. Of these, 12 amplified and were polymorphic in hazelnut, and nine were assigned to linkage groups. We studied the transferability of 276 SSR primer pairs in the Betulaceae. Our study shows that SSR markers developed for Betula and Corylus are highly transferable across species within the genus of origin, and many are also transferable across genera in the Betulaceae. Transferable and polymorphic loci are well suited for genome studies in the Betulaceae and will allow alignment of the linkage maps for silver birch $(B$. pendula) and european hazelnut.

\section{Literature Cited}

Barbara, T., C. Palma-Silva, G.M. Paggi, F. Bered, M.F. Fay, and C. Lexer. 2007. Cross-species transfer of nuclear microsatellite markers: Potential and limitations. Mol. Ecol. 16:3759-3767.

Bassil, N.V., R. Botta, and S.A. Mehlenbacher. 2005a. Microsatellite markers in hazelnut: Isolation, characterization and cross-species amplification. J. Amer. Soc. Hort. Sci. 130:543-549.

Bassil, N.V., R. Botta, and S.A. Mehlenbacher. 2005b. Additional microsatellite markers of the european hazelnut. Acta Hort. 686:105110.

Bennetzen, J.L. 2000. Comparative sequence analysis of plant nuclear genomes: Microcolinearity and its many exceptions. Plant Cell 12:1021-1029.

Boccacci, P., A. Akkak, N.V. Bassil, S.A. Mehlenbacher, and R. Botta. 2005. Characterization and evaluation of microsatellite loci in european hazelnut (C. avellana) and their transferability to other Corylus species. Mol. Ecol. Notes 5:934-937.

Botstein, D., R.L. White, M.H. Skolnick, and R.W. Davies. 1980. Construction of a genetic linkage map in man using restriction fragment length polymorphisms. Am. J. Hum. Genet. 32:314-331.

Botta, R., G.M. Emanuel, S. Sacerdote, and R. Vallania. 1986. Indagine cariologica in alcune specie del genere Corylus (in Italian). Rivista di Ortoflorfrutticoltura Italiana 70:323-329.

Chen, Z. and J. Li. 2004. Phylogenetics and biogeography of Alnus (Betulaceae) inferred from sequences of nuclear ribosomal DNA ITS region. Int. J. Plant Sci. 165:325-335.

Chen, Z.D., S.R. Manchester, and H.Y. Sunday. 1999. Phylogeny and evolution of the Betulaceae as inferred from DNA sequences, morphology, and paleobotany. Amer. J. Bot. 86:1168-1181.

Cipriani, G., G. Lot, W.G. Huang, M.T. Marrazzo, E. Peterlunger, and R. Testolin. 1999. AC/GT and AG/CT microsatellite repeats in peach [Prunus persica (L) Batsch]: Isolation, characterisation and crossspecies amplification in Prunus. Theor. Appl. Genet. 99:65-72.

Davis, J.W., D. Henderson, M. Kobayashi, and M.T. Clegg. 1998. Genealogical relationships among cultivated avocado as revealed through RFLP analysis. J. Hered. 89:319-323.

Decroocq, V., M.G. Fave, L. Hagen, L. Bordenave, and S. Decroocq. 2003. Development and transferability of apricot and grape EST microsatellite markers across taxa. Theor. Appl. Genet. 106:912922.

Dirlewanger, E., E. Graziano, T. Joobeur, F. Garriga-Caldere, P. Cosson, W. Howad, and P. Arus. 2004. Comparative mapping and marker-assisted selection in Rosaceae fruit crops. Proc. Natl. Acad. Sci. USA 29:9891-9896.

Ellis, J.R. and J.M. Burke. 2007. EST-SSRs as a resource for population genetic analyses. Heredity 99:125-132.
Erdoğan, V. and S.A. Mehlenbacher. 2000. Phylogenetic relationships of Corylus species (Betulaceae) based on nuclear ribosomal DNA ITS region and chloroplast matK gene sequences. Syst. Bot. 25:727737.

Forest, F. and A. Bruneau. 2000. Phylogenetic analysis, organization, and molecular evolution of the nontranscribed spacer of $5 \mathrm{~S}$ ribosomal RNA genes in Corylus (Betulaceae). Int. J. Plant Sci. 161:793806.

Gökirmak, T., S.A. Mehlenbacher, and N.V. Bassil. 2009. Characterization of european hazelnut (Corylus avellana) cultivars using SSR markers. Genet. Resources Crop Evol. 56:147-172.

Gürcan, K. 2009. Simple sequence repeat marker development and use in european hazelnut (Corylus avellana L.). PhD Diss., Oregon State Univ., Corvallis.

Gürcan, K., S.A. Mehlenbacher, R. Botta, and P. Boccacci. 2010. Development, characterization, segregation, and mapping of microsatellite markers for european hazelnut (Corylus avellana L.) from enriched genomic libraries and usefulness in genetic diversity studies. Tree Genet. Genomes, doi: 10.1007/s11295-010-0269-y.

Heesacker, A., V.K. Kishore, W. Gao, S. Tang, J.M. Kolkman, A. Gingle, M. Matvienko, A. Kozik, R.M. Michelmore, Z. Lai, L.H. Rieseberg, and S.J. Knapp. 2008. SSRs and INDELs mined from the sunflower EST database: Abundance, polymorphisms, and crosstaxa utility. Theor. Appl. Genet. 117:1021-1029.

Hoffmann-Sommergruber, K., M. Vanek-Krebitz, C. Radauer, J. Wen, F. Ferreira, O. Scheiner, and H. Breiteneder. 1997. Genomic characterization of members of the Bet $\mathrm{v} 1$ family: Genes coding for allergens and pathogenesis-related proteins share intron positions. Gene 197:91-100.

Huang, X. and A. Madan. 1999. CAP3: A DNA sequence assembly program. Genome Res. 9:868-877.

Järvinen, P., J. Lemmetyinen, O. Savolainen, and T. Sopanen. 2003. DNA sequence variation in BpMADS2 gene in two populations of Betula pendula. Mol. Ecol. 12:369-384.

Järvinen, P., A. Palmé, L.O. Morales, M. Lännenpää, M. Keinänen, T. Sopanen, and M. Lascoux. 2004. Phylogenetic relationships of Betula species (Betulaceae) based on nuclear $A D H$ and chloroplast matK sequences. Amer. J. Bot. 91:1834-1845.

Kulju, K.K.M., M. Pekkinen, and S. Varvio. 2004. Twenty-three microsatellite primer pairs for Betula pendula (Betulaceae). Mol. Ecol. Notes 4:471-473.

Liu, K. and S.V. Muse. 2005. PowerMarker: An integrated analysis environment for genetic marker analysis. Bioinformatics 21:21282129.

Lunde, C.F., S.A. Mehlenbacher, and D.C. Smith. 2000. Survey of hazelnut cultivars for response to eastern filbert blight inoculation. HortScience 35:729-731.

Lüttkopf, D., U. Müller, P.S. Skov, B.K. Ballmer-Weber, B. Wüthrich, K. Skamstrup Hansen, L.K. Poulsen, M. Kästner, D. Haustein, and S. Veiths. 2001. Comparison of four variants of a major allergen in hazelnut (Corylus avellana) Cor a 1.04 with the major hazel pollen allergen Cor a 1.01. Mol. Immunol. 38:515-525.

Mehlenbacher, S., R. Brown, E. Nouhra, T. Gökirmak, N.V. Bassil, and T. Kubisiak. 2006. A genetic linkage map for hazelnut (Corylus avellana L.) based on RAPD and SSR markers. Genome 49:122133.

National Center for Biotechnology Information. 2010. National Center for Biotechnology Information. 30 Mar. 2010. <http:// www.ncbi.nih.gov>.

Navarro, E., J. Bousquet, A. Moiroud, A. Munive, D. Piou, and P. Normand. 2003. Molecular phylogeny of Alnus (Betulaceae), inferred from nuclear ribosomal DNA ITS sequences. Plant Soil 254:207-217.

Nei, M. 1973. Analysis of gene diversity in subdivided populations. Proc. Natl. Acad. Sci. USA 70:3321-3323.

Oygu, K., Y. Tsuda, T. Sugaya, H. Yoshimaru, and Y. Ide. 2003. Identification and characterization of microsatellite loci in Betula maximowicziana Regel. Mol. Ecol. Notes 3:268-269. 
Pandian, A., R. Ford, and P.W.J. Taylor. 2000. Transferability of sequence tagged microsatellite site (STMS) primers across four major pulses. Plant Mol. Biol. Rpt. 18:395.

Paterson, A.H., M. Freeling, and T. Sasaki. 2007. Grains of knowledge: Genomics of model cereals. Genome Res. 15:1643-1650.

Pekkinen, M., S. Varvio, K.K.M. Kulju, H. Kärkkäinen, S. Smolander, A. Viherä-Aarnio, V. Koski, and M.J. Sillanpää. 2005. Linkage map of birch, Betula pendula Roth, based on microsatellites and amplified fragment length polymorphisms. Genome 48:619-625.

Pierantoni, L., K.H. Cho, I.S. Shin, R. Chiodini, S. Tartarini, L. Dondini, S.J. Kang, and S. Sansavini. 2004. Characterisation and transferability of apple SSRs to two european pear $F_{1}$ populations. Theor. Appl. Genet. 109:1519-1524.

Rallo, P., I. Tenzer, C. Gessler, L. Baldoni, G. Dorado, and A. Martín. 2003. Transferability of olive microsatellite loci across the genus Olea. Theor. Appl. Genet. 107:940-946.

Rozen, S. and H.J. Skaletsky. 2000. Primer3 on the WWW for general users and for biologist programmers, p. 365-386. In: S. Krawetz and S. Misener (eds.). Bioinformatics methods and protocols: Methods in molecular biology. Humana Press, Totowa, NJ.

Santino, A., A. De Paolis, A. Gallo, A. Quarta, R. Casey, and G. Mita. 2003. Biochemical and molecular characterization of hazelnut (Corylus avellana) seed lipoxygenases. Eur. J. Biochem. 270: 4365-4375.

Schenk, M., C.N. Thienpont, W. Koopman, L. Gilissen, and M. Smulders. 2008. Phylogenetic relationships in Betula (Betulaceae) based on AFLP markers. Tree Genet. Genomes 4:911-924.

Schocker, F., D. Lüttkopf, S. Scheurer, A. Petersen, A. CisteroBahima, E. Enrique, S. Vieths, and W. Becker. 2002. Hazelnut LTP, Cor a 8: Molecular cloning and clinical relevance. J. Allergy Clin. Immunol. 109:302.
Snow, N. and P. Goldblatt. 1992. Chromosome numbers in Ticodendron (Fagales, Ticodendraceae). Ann. Mo. Bot. Gard. 79:906-907. Swoboda, I., A. Jilek, F. Ferreira, E. Engel, K. Hoffman-Sommergruber, O. Scheiner, D. Kraft, H. Breiteneder, E. Pittenauer, E. Schmid, O. Vicente, E. Heberle-Bors, H. Ahorn, and M. Breitenbach. 1995. Isoforms of Bet $\mathrm{v}$ 1, the major birch pollen allergen, analyzed by liquid chromatography, mass spectrometry, and cDNA cloning. J. Biol. Chem. 270:2607-2613.

Temnykh, S., G. DeClerck, A. Lukashova, L. Lipovich, S. Carinhour, and S. McCouch. 2001. Computational and experimental analysis of microsatellites in rice (Oryza sativa L.): Frequency, length variation, transposon associations, and genetic marker potential. Genome Res. 11:1441-1452.

Truong, C., A.E. Palme, F. Fleber, and Y. Naciri-Graven. 2005. Isolation and characterization of microsatellite markers in the tetraploid birch, Betula pubescens ssp. tortuosa. Mol. Ecol. Notes 5:96-98.

Van Ooijen, J.W. and R.E. Voorrips. 2001. JoinMap ${ }^{\circledR}$, version 3.0: Software for the calculation of genetic linkage maps. Plant Research International, Wageningen, The Netherlands.

Varshney, R.K., R. Sigmund, A. Börner, V. Korzun, N. Stein, M.E. Sorrells, P. Langridge, and A. Graner. 2005. Interspecific transferability and comparative mapping of barley EST-SSR markers in wheat, rye and rice. Plant Sci. 168:195-202.

Wu, B., C. Lian, and T. Hogetsu. 2002. Development of microsatellite markers in white birch (Betula platyphylla var. japonica). Mol. Ecol. Notes 2:413-415.

Yoo, K.O. and J. Wen. 2002. Phylogeny and biogeography of Carpinus and subfamily Coryloideae (Betulaceae). Int. J. Plant Sci. 163:641-650.

Zhang, L.Y., M. Bernard, P. Leroy, C. Feuillet, and P. Sourdille. 2005. High transferability of bread wheat EST-derived SSRs to other cereals. Theor. Appl. Genet. 111:677-687. 